\title{
Regional validation of the use of diatoms in ice cores from the Antarctic Peninsula as a Southern Hemisphere Westerly Wind proxy
}

\author{
Dieter R. Tetzner ${ }^{1,2}$, Elizabeth R. Thomas ${ }^{1}$, Claire S. Allen ${ }^{1}$, Mackenzie M. Grieman ${ }^{2}$ \\ ${ }^{1}$ British Antarctic Survey, Ice Dynamics and Paleoclimate, Cambridge, CB3 OET, UK \\ $5 \quad{ }^{2}$ Department of Earth Sciences, University of Cambridge, Cambridge, CB2 3EQ, UK
}

Correspondence to: Dieter R. Tetzner (dietet95@bas.ac.uk)

\begin{abstract}
The Southern Hemisphere Westerly Winds are among the most important drivers of recently observed environmental changes in West Antarctica. However, the lack of long-term wind records in this region hinders our ability to assess the long-term context of these variations. Ice core proxy records yield valuable information about past environmental changes, although current proxies present limitations when aiming to reconstruct past winds. Here we present the first regional wind study based on the novel use of diatoms preserved in Antarctic ice cores. We assess the temporal variability in diatom abundance and its relation to regional environmental parameters spanning a 20-year period across three sites in the southern Antarctic Peninsula and Ellsworth Land, Antarctica. Correlation analyses reveal that the temporal variability of diatom abundance from high elevation ice core sites is driven by changes in wind strength over the core of the Southern Hemisphere

15 Westerly Wind belt. Validating the use of diatoms preserved in ice cores from the Southern Antarctic Peninsula and Ellsworth Land as a proxy for reconstructing past variations in wind strength over the Pacific sector of the Southern Hemisphere Westerly Wind belt.
\end{abstract}

\section{Introduction}

Winds over the Southern Ocean (circumpolar westerlies) play a key role in driving the exchange of heat and carbon dioxide 20 between the ocean and atmosphere (Russell et al., 2006; Quéré et al., 2007; Hodgson and Sime, 2010; Landschutzer et al. 2015). In recent decades, the circumpolar wind belt has increased in strength and has shifted towards the Antarctic continent, constituting one of the strongest climatic trends in the Southern Hemisphere (Thompson and Solomon, 2002, Gille et al. 2008, Young et al. 2011). These atmospheric changes have been linked as drivers of the widespread warming observed in the Antarctic Peninsula (AP) (Thomas et al., 2009; Thomas and Tetzner, 2018; Turner et al., 2020) and West Antarctica (WA) 25 (Thomas et al. 2013) and as the mechanism behind the enhanced upwelling of deep and relatively warm, CO2-rich, oceanic water (Nakayama et al., 2018). The upwelling of circumpolar deep water has been shown to promote accelerated melting and thinning at the base of the ice shelves (Thoma et al., 2008; Jacobs et al., 2011; Pritchard et al., 2012; Steig et al., 2012; Wåhlin et al., 2013; Dutrieux et al., 2014; Favier et al., 2014; Gille et al., 2014; Joughin et al., 2014; Paolo et al., 2015; Holland et al., 2019), thus, threatening the stability of floating ice shelves along the coastline of the Amundsen-Bellingshausen Seas and 
https://doi.org/10.5194/cp-2021-88

Preprint. Discussion started: 22 July 2021

(c) Author(s) 2021. CC BY 4.0 License.

(c) (i)

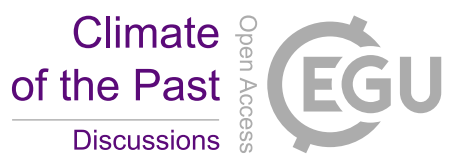

30 ultimately contributing to global sea-level rise (Pritchard et al., 2012). Changes in the circumpolar westerlies have also been linked to an observed pattern of increased snow accumulation in Antarctica over the $20^{\text {th }}$ century, which has mitigated global mean sea level rise (Medley and Thomas., 2019). To assess the context of these recent wind changes, an extended record of wind strength is needed.

Direct meteorological observations in the AP region are sparse, relatively short-term and mostly constrained to coastal regions

35 (Oliva et al., 2017; Thomas and Tetzner, 2018). The scarcity of continuous long-term data can be partly addressed by using climate reanalyses datasets. These datasets comprise model outputs from simulations that are used to interpolate measured climate variables, providing accurate meteorological data in this region for the satellite-era (1979-present) (Tetzner et al., 2019), but are not viable for studying pre-satellite regional climate variability. Climate models can be used to extend the record back in time, however, model simulations from the fifth Coupled Model Intercomparison Project (CMIP5) exhibit strong biases

40 over the Southern Ocean compared with observations (Bracegirdle et al., 2013). Overall, the lack of long-term wind records in the region hinders the possibility to assess the long-term context of the recently observed changes.

Ice cores provide valuable climatic information over a range of timescales (Legrand and Mayewski, 1997). Insoluble mineral dust concentrations in Antarctic ice cores have been widely used to infer past variability in regional-to-hemispheric atmospheric circulation (Röthlisberger et al., 2002; Lambert et al., 2008; Koffman et al., 2014; Delmonte et al., 2020; Laluraj

45 et al., 2020). Geochemical tracers of mineral dust, such as the non-sea-salt component of soluble calcium $\left(\mathrm{nssCa}^{2+}\right) \mathrm{or}$ potassium $\left(\mathrm{nssK}^{+}\right)$, have been used to track changes in the strength and position of the Southern Hemisphere Westerly Wind (SHWW) belt (Dixon et al., 2012; Mayewski et al., 2013). However, these traditional proxies typically originate from South America, Australia and New Zealand and are therefore potentially influenced by environmental changes in these distal source regions (McConnell et al., 2007; Lambert et al., 2008; Wolff et al., 2010; Bullard et al., 2016; Delmonte et al., 2017). Sea salt

50 sodium $\left(\mathrm{ssNa}^{+}\right)$has been previously interpreted as a proxy of increased meridional transport from the Southern Ocean to ice core sites in Antarctica (Kreutz et al., 2000; Goodwin et al., 2004; Kaspari et al., 2005; Mayewski et al., 2013; Vance et al., 2013). However, the $\mathrm{ssNa}^{+}$signal is potentially influenced by inputs from blowing snow above sea ice (Frey et al., 2020) and by the production of ss $\mathrm{Na}^{+}$in 'frost-flowers', as well as by inputs from the open ocean (Huang and Jaeglé, 2017). As frost flowers are precipitated from the surface of freshly formed sea ice (Wagenbach et al., 1998; Rankin et al., 2000), and all these

55 sources are affected by sea ice extent, some studies have reflected on the potential of the ssNa ${ }^{+}$ice core record from Antarctic coastal sites as a proxy of seasonal sea ice extension (Rankin et al., 2002; Wolff et al., 2003; Wolff et al., 2006). These conflicting sources of $\mathrm{ssNa}^{+}$suggest that the variability of the $\mathrm{ssNa}^{+}$record is not entirely driven by changes in winds. The current limitations identified in conventional ice core wind proxies highlight the need to explore new species to reconstruct wind strength.

60 Marine diatoms entrained in Antarctic snow and ice have recently been proposed as an alternative source of information about winds (Allen et al., 2020). Diatoms are unicellular algae with siliceous cell walls that inhabit marine, brackish and freshwater environments throughout the world (Smol and Stoermer, 2010). Despite their aquatic habitats, several studies support that they can be airborne (Chalmers et al., 1996; Gayley et al., 1989; Lichti-Federovich, 1984; McKay et al., 2008; Wang et al., 2008; 
Harper and Mackay, 2010; Spaulding et al., 2010; Hausmann et al., 2011; Budgeon et al., 2012; Papina et al., 2013; Fritz et al., 2015). Marine diatoms can be effectively lifted from the sea-surface microlayer into the atmosphere by wind-induced bubble-bursting and wave-breaking processes (Cipriano and Blanchard, 1981; Farmer et al., 1993). Once in the atmosphere, they can be transported by winds over long distances (Gayley, 1989; McKay et al., 2008; Harper and McKay, 2010). Diatom records have been evaluated at multiple ice core sites in the AP and Ellsworth Land (EL) regions (Tetzner et al., 2021a) to reveal consistent spatial variations and increases in the diatom concentration during the past three decades. Despite the potential the diatom record has shown to reconstruct past wind strength, this proxy requires evaluation against more established ice core wind proxies.

In this study, we evaluate the potential for marine diatoms to reconstruct regional wind strength using an array of three shallow depth ice cores drilled in the AP and EL regions. We investigate the relationship between diatom abundance and changes in environmental parameters to assess the regional consistency of the diatom-based wind proxy. We expand these analyses by comparing the diatom record to traditional ice core wind proxies based on major ions and dust.

\section{Methods}

\subsection{Ice core records and age scales}

Three ice cores from the southern AP and EL were included in this study (Figure 1) (Table 1). The Jurassic ice core (JUR, 140 m) was drilled in the vicinity of Jurassic Nunatak, using the BAS electromechanical drill during the austral summer 2012/2013.

80 The Sky-Blu ice core (SKBL, $21.8 \mathrm{~m}$ ) from the vicinity of Sky-Blu Field Station, southern AP, and the Sherman Island ice core (SHIC, $21.3 \mathrm{~m}$ ) from Eights Coast, were drilled using a Kovacs hand-auger during the austral summer 2019/2020. For JUR, SKBL and SHIC, an ice core chronology was established (Tetzner et al., 2021a) based on their hydrogen peroxide $\left(\mathrm{H}_{2} \mathrm{O}_{2}\right)$ annual cycle that is assumed to peak during the austral summer solstice and to exhibit its minimum during the austral winter (Frey et al., 2006; Thomas et al., 2008). Ice core chronologies were corroborated using the annual cycle of the non-sea salt component of major ions, such as non-sea salt sulphate $\left(\mathrm{nssSO}_{4}{ }^{2-}\right.$ ) (Piel et al., 2006), that is assumed to peak between November and January in this region (Pasteris et al., 2014; Thoen et al., 2018). Ice core chronologies were corroborated with the presence of volcanic tephra in the $2001 \mathrm{CE}$ ice core layer (Tetzner et al., 2021b). The top $15 \mathrm{~m}$ of SKBL included in this work and the full SHIC core were dated back to $1999 \mathrm{CE}$, and the top $36.90 \mathrm{~m}$ of JUR included in this work dated back to $1992 \mathrm{CE}$. The estimated dating error is \pm 3 months for each year and with no accumulated error. 


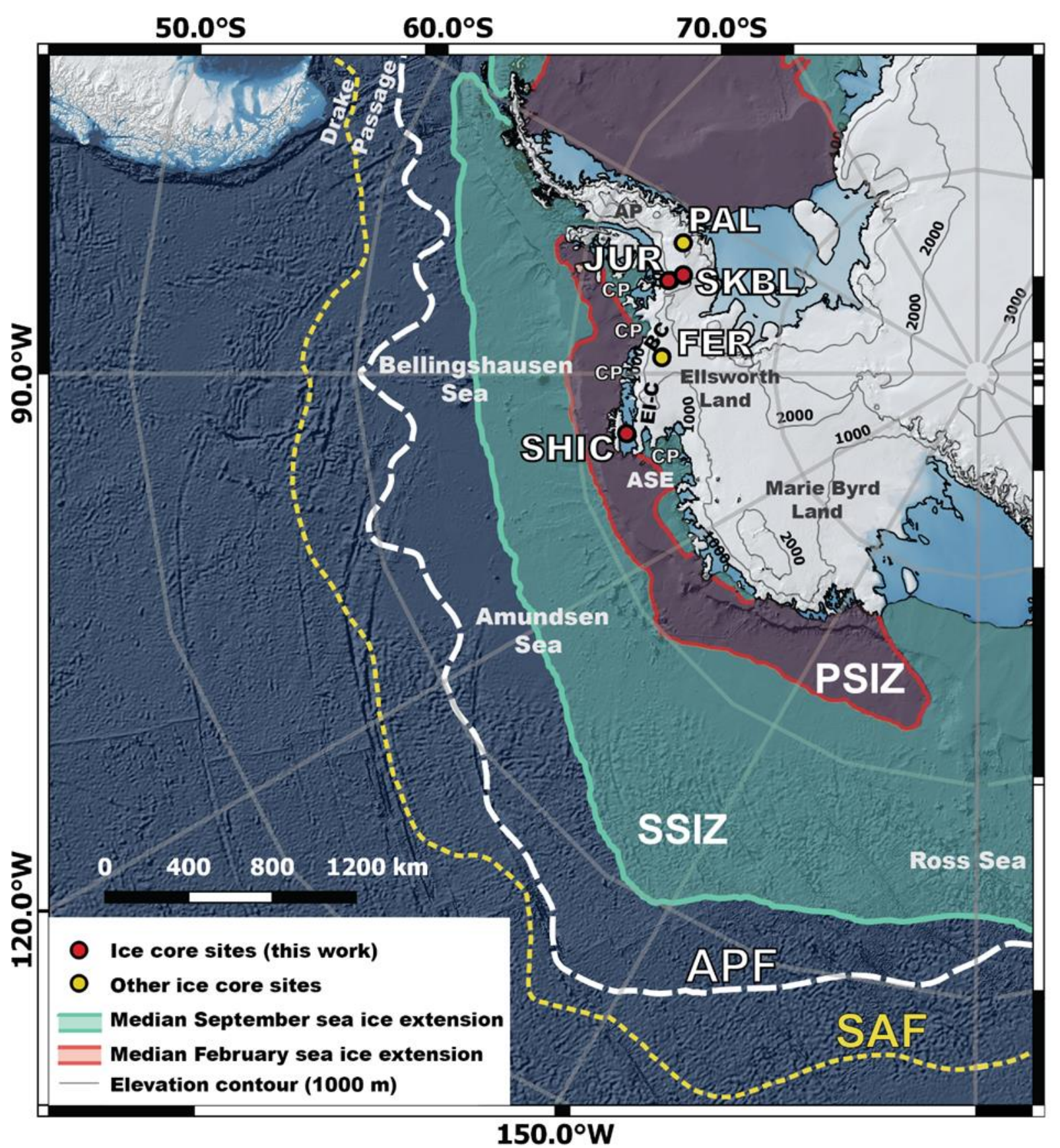

Figure 1. Map showing the location of the ice core sites and main oceanographic features considered in this study. The red circles show the locations of the three ice core sites. The pale green line shows the median September sea ice-extension between $1980-2010$ $\mathrm{CE}$ and the pale green area represents the Seasonal Sea ice Zone (SSIZ). The red line shows the median February sea ice-extension between 1980-2010 CE, and the pale red area represents the Perennial Sea ice Zone (PSIZ). SAF= Sub-Antarctic Front. APF= 95 Antarctic Polar Front. CP= Coastal Polynya. EI-C= Eights Coast. BC= Bryan Coast. ASE=Amundsen Sea Embayment. PAL= Palmer ice core site. FER= Ferrigno ice core site 
Table 1. Summary of each ice core geographical location and main features analysed in this study. SIE= Sea Ice Edge(*) - The distance from SIE reported corresponds to the median for years covering the data interval. September SIE values used for calculations were obtained as distance between the ice core site and the closest point in the northern limit of $15 \%$ sea ice cover. February SIE values used for calculations were obtained as the distance between the ice core site and the closest sea ice free region.

\begin{tabular}{lccllllll}
\hline $\begin{array}{l}\text { Core } \\
\text { name }\end{array}$ & Long & Lat & $\begin{array}{l}\text { Elevation } \\
\text { (m.a.s.l) }\end{array}$ & ANNUAL RECORD & $\begin{array}{l}\text { Total } \\
\text { depth } \\
\text { used (m) }\end{array}$ & \multicolumn{2}{c}{$\begin{array}{l}\text { Distance from } \\
\text { SIE (km)* }\end{array}$} \\
\hline & & & & Years (CE) & \# samples & & Sept & Feb \\
\hline JUR & -73.06 & -74.33 & 1139 & $1992-2012$ & 20 & 36.9 & 1045 & 140 \\
SKBL & -71.59 & -74.85 & 1419 & $1999-2019$ & 20 & 15.0 & 1148 & 200 \\
SHIC & -99.63 & -72.67 & 474 & $1999-2019$ & 20 & 21.3 & 753 & 130 \\
\hline
\end{tabular}

\subsection{Sample preparation and analyses}

All ice cores included in this study were cut using a band-saw with a steel blade. Discrete ice core samples were cut at 5-cm resolution for ion chromatographic analyses using reagent-free Dionex ICS-2500 anion and IC 2000 cation systems in a class100 cleanroom. Major ion concentrations were used to calculate the ionic contributions from marine and continental sources.

105 The marine sea salt fraction of sodium $\left(\mathrm{ssNa}^{+}\right)$and the non-sea salt fraction of calcium $\left(\mathrm{nssCa}^{2+}\right)$ were calculated using Equation (1) and Equation (2):

$$
\begin{aligned}
& {\left[\mathrm{ssNa}^{+}\right]=\left[\mathrm{Na}^{+}\right]-\left[\mathrm{nssCa}^{2+}\right] / \mathrm{R}_{\text {crust }}} \\
& {\left[\mathrm{nssCa}^{2+}\right]=\left[\mathrm{Ca}^{2+}\right]-\left[\mathrm{ssNa}^{+}\right] * \mathrm{R}_{\text {sea water } \mathrm{Ca} / \mathrm{Na}}}
\end{aligned}
$$

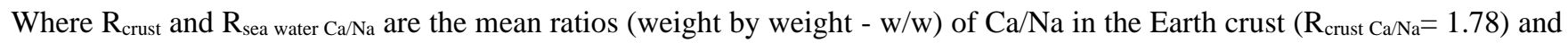
in bulk sea water $\left(\mathrm{R}_{\text {sea water } \mathrm{Ca} / \mathrm{Na}}=0.038\right)$, respectively (Bowen, 1979). The non-sea salt fraction of potassium $\left(\mathrm{nssK} \mathrm{K}^{+}\right.$) was calculated using the following Equation (3):

$\left[\mathrm{nssK}^{+}\right]=\left[\mathrm{K}^{+}\right]-\left[\mathrm{ssNa}^{+}\right] * \mathrm{R}_{\text {sea water K/Na }}$

Where $R_{\text {sea water } K / N a}$ is the mean ratio (weight by weight - w/w) of $K / N a$ in bulk sea water $\left(R_{\text {sea water } K / N a}=0.036\right)$ (Piel et al., 2006).

115 Microparticle Concentration (MPC) was measured on each ice core using a flow-through Klotz Abakus laser particle counter connected to a continuous ice core melter system at the British Antarctic Survey (Grieman et al., 2021).

All diatom samples were extracted by filtration. Ice core meltwater was filtered through polycarbonate membrane filters (pore diameter $1.0 \mu \mathrm{m}$ ) and subsequently scanned in a scanning electron microscope (SEM) following the method presented in Tetzner et al. (2021c). Observations of diatom preservation were based on the visual identification of characteristic frustule dissolution features and degradation described in Warnock and Scherer (2015). Diatom frustules and fragments less than $5 \mu \mathrm{m}$ were excluded from counting and identification. Diatom counts per sample (n) included all diatom valves, partially obscured valves and diatom fragments identified in each sample. After processing, diatom counts per sample (n) were represented as their temporal equivalent, diatom abundance $\left(\mathrm{n} \mathrm{a}^{-1}\right)$. 
All correlations are based on detrended data and calculated using the Pearson's linear correlation (R). Time series linear are reported as austral summer (December to February, DJF), autumn (March to May, MAM), winter (June to August, JJA) and spring (September to November, SON).

\subsection{Climate reanalyses and sea ice extension data}

Monthly reanalysis fields from the fifth generation of the European Center for Medium-Range Weather Forecasts (ECMWF),

ERA5 (Hersbach and Dee, 2016), were used to obtain spatial correlations between ice core records and environmental parameters. Three fields were used to perform spatial correlation analyses: wind speed (10 $\mathrm{m}$ wind speed), precipitation and sea ice cover. ERA5 datasets provide hourly data available at 0.25 -degree resolution $(\sim 31 \mathrm{~km})$ since $1979 \mathrm{CE}$.

Sea ice extension data were obtained from the Sea Ice Index, Version 3 dataset (Fetterer et al., 2017) from the National Snow and Ice Data Centre (NSIDC), providing monthly sea ice concentrations at $25 \mathrm{~km}$ resolution from 1979 to 2021 CE. September

135 sea ice limits (defined as the median northerly extent of $15 \%$ sea ice cover) were considered the annual sea ice maximum and February sea ice limits (defined as the median northerly extent of $15 \%$ sea ice cover) were considered the annual sea ice minimum (Thomas et al., 2019).

\subsection{Statistical analyses}

For each ice core site, the diatom abundance was compared to conventional ice core wind proxies $\left(\mathrm{ssNa}^{+}, \mathrm{nssCa}^{2+}, \mathrm{nssK}^{+}\right.$and

140 MPC) and to records of methane sulphonic acid (MSA), a traditional sea ice proxy. All correlations were based on annual averages. Spatial correlations were based on detrended data and calculated using the Pearson's linear correlation (R) over the South Pacific sector, from $180^{\circ} \mathrm{W}$ to $60^{\circ} \mathrm{W}$ and $40^{\circ} \mathrm{S}$ to $90^{\circ} \mathrm{S}$, selected based on air-mass pathways reaching the ice core sites (Thomas and Bracegirdle, 2015). Based on the records of September sea ice cover between 1992-2020 CE (Fetterer et al., 2017), spatial correlations for sea ice cover were calculated over a reduced region (between $180^{\circ} \mathrm{W}$ to $60^{\circ} \mathrm{W}$ and $55^{\circ} \mathrm{S}$ to $90^{\circ} \mathrm{S}$ ).

145 All linear correlations were calculated over a 20-year period (1992-2012 CE for JUR and 1999-2019 CE for SHIC and SKBL). Since diatom concentrations at SHIC peak during the austral summer (Tetzner et al., 2021a), spatial correlations for the SHIC diatom record were also calculated over 6-month period covering the austral spring \& summer season (September-February).

\section{Results}

\subsection{Jurassic ice core (JUR)}

\section{3.1.1 Chemistry, MPC and diatom abundance annual records}

The JUR chemical, MPC and diatom abundance records are characterized by positive trends during the 1992-2012 CE period (Figure 2). Of them, only $n s s \mathrm{Ca}^{2+}, \mathrm{nssK}^{+}$and $\mathrm{ssNa}^{+}$were statistically significant $(\mathrm{p}<0.05)$ (Appendix A - Table A1). The 
https://doi.org/10.5194/cp-2021-88

Preprint. Discussion started: 22 July 2021

(c) Author(s) 2021. CC BY 4.0 License.

(c) (1)

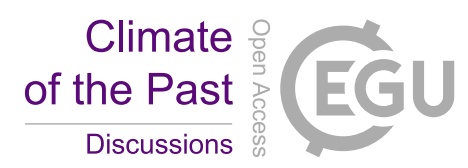

$\mathrm{nssCa}^{2+}$ shows a steady increase after $2005 \mathrm{CE}$, reaching a maximum (136.46 ppb) between 2009-2010 CE. The nssK ${ }^{+}$shows a similar pattern with values increasing steadily after $2001 \mathrm{CE}$, and doubling by 2011-2012 CE. The ssNa ${ }^{+}$has a consistent

155 positive trend $\left(2.01 \mathrm{ppb} \mathrm{y}^{-1}, \mathrm{p}<0.05\right)$ from 1992 to $2012 \mathrm{CE}$, with a single major increase in $2001 \mathrm{CE}$. The MSA displays an overall decrease between 1992-2002 CE, followed by a general increase during 2002-2012 CE. Similarly, the MPC exhibits an increase during 1992-2012 CE with its lowest values during $1997 \mathrm{CE}$. The diatom abundance is moderately variable between 1992-2004 CE, followed by a marked increase after 2004 CE, reaching its highest value during 2009-2010 CE (Figure 2). 
$\multimap$ JUR $\multimap$ SKBL $\multimap$ SHIC
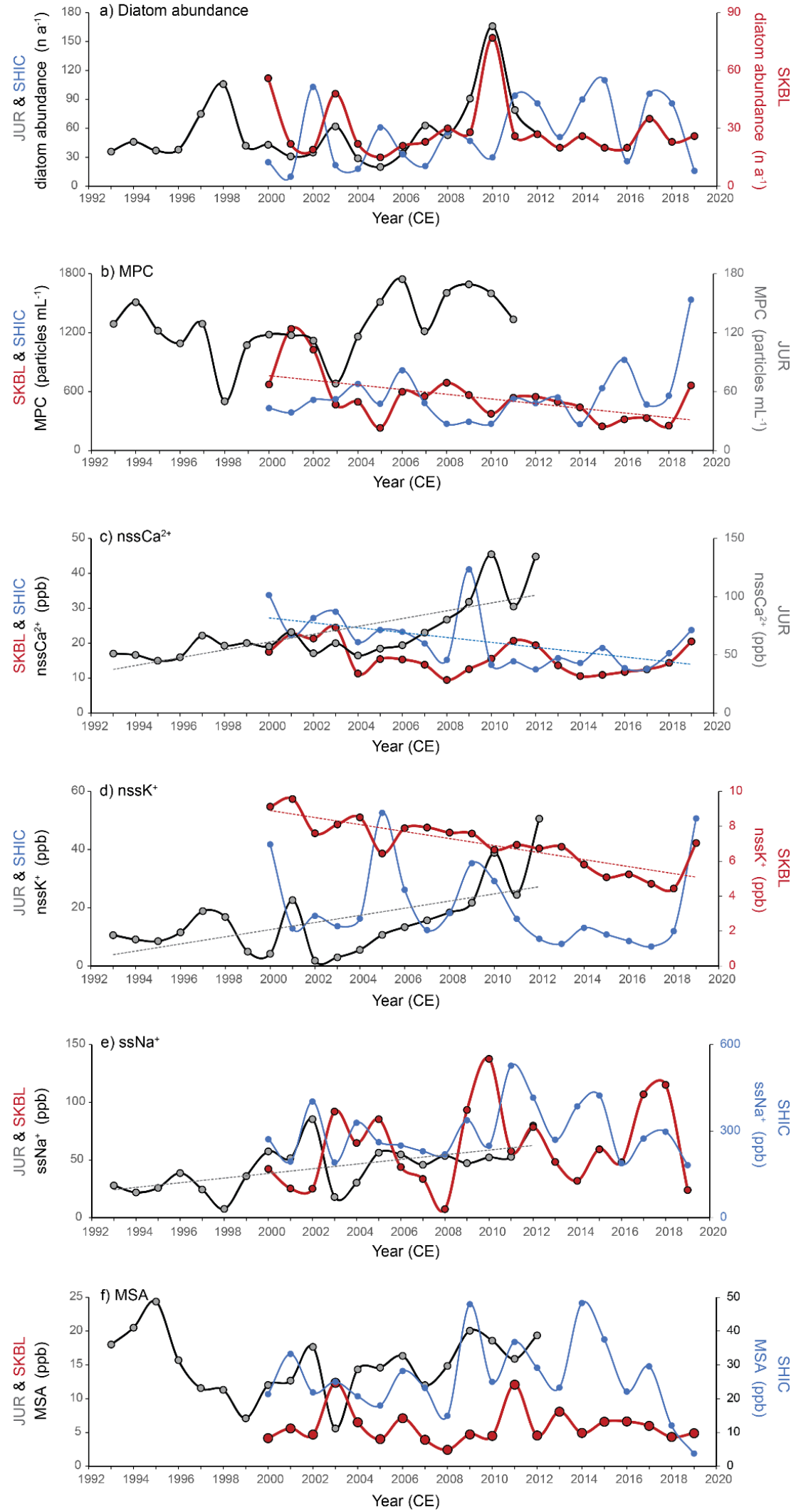
https://doi.org/10.5194/cp-2021-88

Preprint. Discussion started: 22 July 2021

(c) Author(s) 2021. CC BY 4.0 License.

(c) (i)

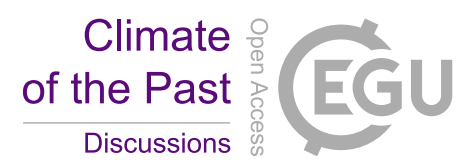

160 Figure 2. Time series of chemical species, MPC and diatom abundance for each ice core site. Data points represent the annual austral winter-to-winter average and were plotted over the correspondent austral summer. Colour-coded dashed lines show statistically significant linear trends $(\mathbf{p}<0.05)$. MPC record from JUR covers the interval 1992-2011 CE.

\subsubsection{Environmental correlations}

All records (excluding MSA) presented strong and significant correlations with wind strength $(R \leq-0.6 \& R \geq 0.6, p<0.05)$

(Figure 3). Diatom abundance is positively correlated with wind strength $(0.6 \leq R \leq 0.67, p<0.05)$ over a latitudinal band at the northern limit of the Amundsen Sea $\left(\sim 60^{\circ} \mathrm{S}\right)$, and negatively correlated with the sea ice cover north of the SHIC ice core drilling site $(-0.6 \geq R \geq-0.69, p<0.05)$. The MPC is positively correlated with wind strength over the east coast of Argentina $(0.6 \leq \mathrm{R} \leq 0.73, \mathrm{p}<0.05)$. The $n s s \mathrm{Ca}^{2+}$ exhibits a positive correlation with wind strength $(0.6 \leq \mathrm{R} \leq 0.62, \mathrm{p}<0.05)$, and with precipitation $(0.6 \leq \mathrm{R} \leq 0.77, \mathrm{p}<0.05)$, off the western coast of southern South America. The nssK ${ }^{+}$shows a positive correlation with wind strength $(0.6 \leq \mathrm{R} \leq 0.66, \mathrm{p}<0.05)$ over the Amundsen Sea. The $s \mathrm{Na}^{+}$is positively correlated with wind strength over the Drake Passage $(0.6 \leq R \leq 0.7, p<0.05)$ and over Ellsworth Land $(0.6 \leq R \leq 0.63, p<0.05)$. No significant correlations were identified with wind strength or precipitation at, or near, the JUR ice core drilling site. No strong correlations $(R \geq 0.6$ or $R \leq-$ $0.6)$ between the MSA record and sea ice cover were identified in the region.

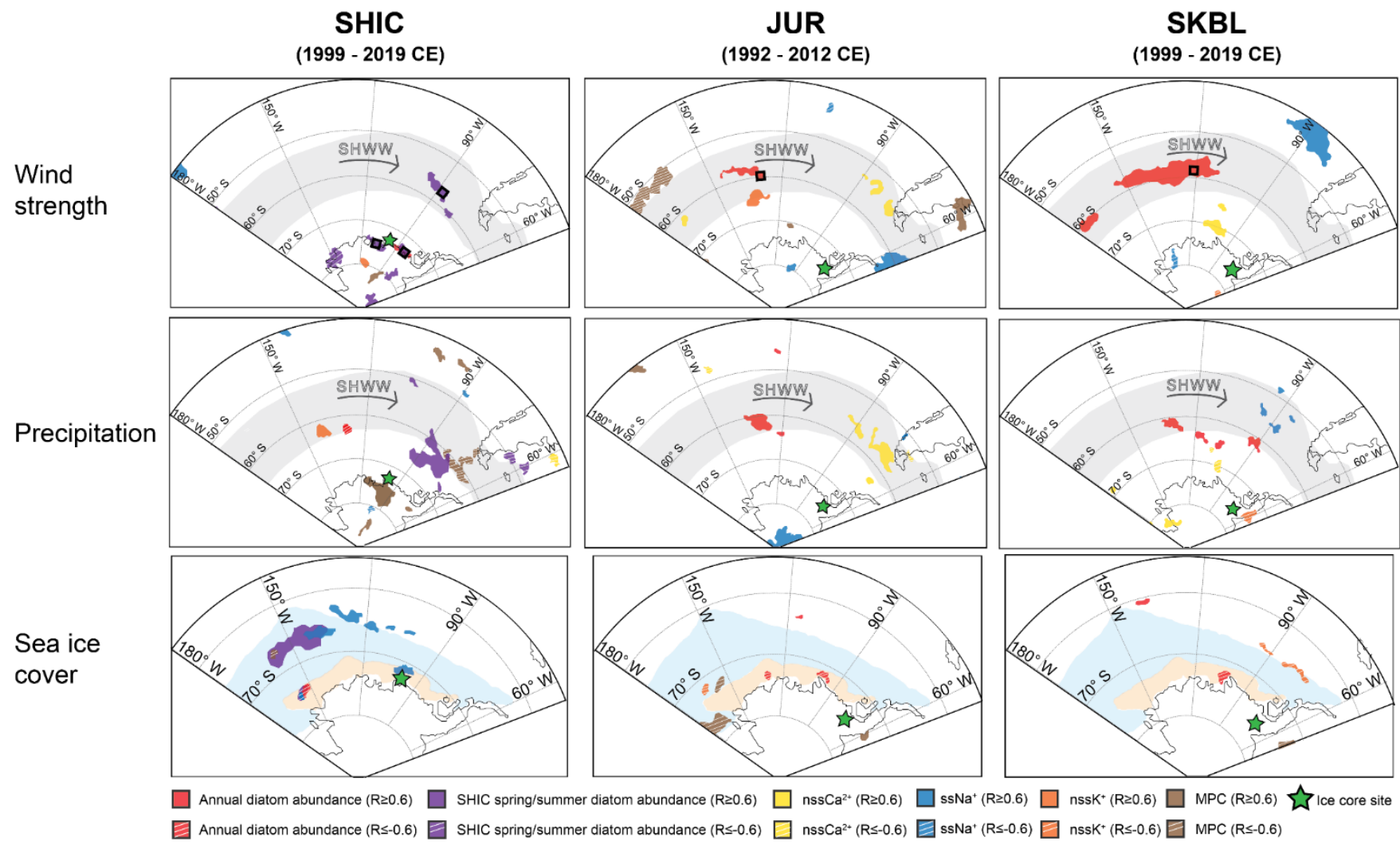

175 Figure 3. Regional maps showing spatial correlations between environmental parameters and chemical species, MPC and diatom abundance. Colour-coded polygons in the maps indicate highly correlated regions $(R \geq 0.6$ or $R \leq-0.6)$. All polygons plotted are statistically significant $(\mathbf{p}<0.05)$. Pale grey latitudinal band indicates the core of the Southern Hemisphere Westerly Wind (SHWW) 
belt. Pale blue polygons indicate the region covered by seasonal sea ice. Pale orange polygons indicate the region covered by perennial sea ice. Black squares represent a $1^{\circ} \times 1^{\circ}$ quadrant around the point of highest correlation (QHC) between wind strength and diatom abundance. Spatial correlations between MSA and environmental parameters were excluded because they were below the threshold $(R<0.6, R>-0.6$ or $\mathbf{p}>0.05)$. Regional maps only present areas of spatial correlation larger $\operatorname{than} 1^{\circ} \times 1^{\circ}$.

\subsection{Sky-Blu ice core (SKBL)}

\subsubsection{Chemistry, MPC and diatom abundance annual records}

The SKBL chemical, MPC and diatom abundance records are characterized by negative trends during the 1999-2019 CE

185 period (Figure 2) (Appendix A - Table A1), with the exception of $\mathrm{ssNa}^{+}$which exhibits a positive trend. Among these trends, only MPC and nssK ${ }^{+}$exhibited linear trends that were statistically significant $(\mathrm{p}<0.05)$. The diatom abundance is characterized by moderate interannual variability and single major increases during 1999-2000, 2002-2003 and 2009-2010 CE. The later presenting the absolute highest value (77 $\left.\mathrm{n} \mathrm{a}^{-1}\right)$. Major increases in MSA were also registered during $2002 \mathrm{CE}$ and $2010 \mathrm{CE}$. (Figure 2).

\subsubsection{Environmental correlations}

The diatom abundance, chemical and MPC records from SKBL were compared to environmental parameters over the 19992019 CE period (Figure 3). Two records are highly correlated with wind strength, the diatom abundance and ssNa ${ }^{+}$. Diatom abundance exhibits a positive correlation with wind strength $(0.6 \leq \mathrm{R} \leq 0.78, \mathrm{p}<0.05)$ over a latitudinal band $\left(\sim 60^{\circ} \mathrm{S}\right)$ extending from the Ross Sea to the Amundsen Sea and a negative correlation with the sea ice cover $(-0.6 \geq R \geq-0.71, p<0.05)$ over the

195 Amundsen Sea Embayment. The $\mathrm{ssNa}^{+}$is positively correlated with wind strength $(0.6 \leq \mathrm{R} \leq 0.75$, $\mathrm{p}<0.05)$ off the west coast of South America at $\sim 45^{\circ} \mathrm{S}$. No correlations were identified between the ice core records and wind strength or precipitation over the SKBL ice core drilling site. No strong correlations $(\mathrm{R} \geq 0.6$ or $\mathrm{R} \leq-0.6)$ between the MSA record and sea ice cover were identified in the region.

\subsection{Sherman Island ice core (SHIC)}

\section{3.3.1 Chemistry, MPC and diatom abundance annual records}

The SHIC chemical, MPC and diatom abundance records present contrasting features over the 1999-2019 CE period (Figure 2) (Appendix A - Table A1). Negative linear trends are observed in nssCa ${ }^{2+}\left(-0.7 \mathrm{ppb} \mathrm{y}^{-1}, \mathrm{p}^{2} 0.05\right)$ and nssK $\mathrm{H}^{+}\left(-0.48 \mathrm{ppb}^{-1}\right.$, $\mathrm{p}>0.05)$. The $\mathrm{ssNa}^{+}$exhibits a positive trend (1.61 $\left.\mathrm{ppb} \mathrm{y}^{-1}, \mathrm{p}>0.05\right)$ with values reaching an absolute maximum during $2011-$ 2012 CE. The MSA was relatively constant over the 1999-2014 CE period. After 2014 CE, MSA decreases, reaching its 205 absolute minimum between 2018-2019 CE. The MPC shows a steady increase after 2008-2009 CE, reaching its highest value in 2018-2019 CE. The diatom abundance exhibits a positive trend (2.16 $\left.\mathrm{n} \mathrm{a}^{-1}, \mathrm{p}>0.05\right)$ with a strong interannual variability which describes a semi-periodic 3-year pattern (Figure 2). 


\subsubsection{Environmental correlations}

The diatom abundance, chemical and MPC records from SHIC were compared to environmental parameters over the 1999-

2019 CE period (Figure 3). Diatom abundance, MPC and $\mathrm{ssNa}^{+}$are highly correlated with wind strength over the 1999-2019 CE period. Annual diatom abundance is positively correlated with wind strength $(0.6 \leq R \leq 0.61, p<0.05)$ over the Bryan Coast sector. The spring/summer diatom abundance is positively correlated with wind strength over a latitudinal band at the northern limit of the Bellingshausen Sea $\left(\sim 60^{\circ} \mathrm{S}\right)(0.6 \leq \mathrm{R} \leq 0.64$, $\mathrm{p}<0.05)$, over the Bryan Coast $(0.6 \leq \mathrm{R} \leq 0.64, \mathrm{p}<0.05)$ and over the Amundsen Sea Embayment $(0.6 \leq \mathrm{R} \leq 0.71, \mathrm{p}<0.05)$. In parallel, the spring/summer diatom abundance is positively correlated with the sea ice cover over the Amundsen Sea $(0.6 \leq \mathrm{R} \leq 0.81, \mathrm{p}<0.05)$. MPC is positively correlated with precipitation $(0.6 \leq \mathrm{R} \leq 0.66, \mathrm{p}<0.05)$ over the SHIC drilling site. Conversely, MPC is negatively correlated with precipitation off the southern coast of South America $(-0.6 \geq R \geq-0.65, \mathrm{p}<0.05)$. The $s \mathrm{Na}^{+}$is positively corelated with sea ice $(0.6 \leq \mathrm{R} \leq 0.7, \mathrm{p}<0.05)$ to the west and north-west of the SHIC drilling site. No clear correlations were identified with the $\mathrm{nssCa}^{2+}$ and $\mathrm{nssK}^{+}$records. No strong correlations ( $\mathrm{R} \geq 0.6$ or $\mathrm{R} \leq-0.6$ ) between the MSA record and sea ice cover were identified for the SHIC site.

\subsection{Correlation of ice core records}

Linear correlations were calculated between the annual chemical, MPC and diatom abundance records across all ice core sites (Supplementary material - Table S1). Strong positive and statistically significant $(\mathrm{p}<0.05)$ correlations were identified between $\mathrm{nssCa}^{2+}$ and $\mathrm{nssK}^{+}$in SHIC and JUR $(\mathrm{R}=0.54$ and $\mathrm{R}=0.88$, respectively) and between MPC and MSA in SHIC and JUR ( $\mathrm{R}=-$ 0.55 and $\mathrm{R}=0.65$, respectively). Diatom abundance and $\mathrm{ssNa}^{+}$were the only components to exhibit strong and significant correlations ( $\mathrm{p}<0.05$ ) across all the ice core sites $(\mathrm{R}=0.78, \mathrm{R}=-0.46$ and $\mathrm{R}=0.52$, for SHIC, JUR and SKBL, respectively). The only statistically significant correlation in the same proxy across the sites was between diatom abundance in the JUR and SKBL cores $(\mathrm{R}=0.84, \mathrm{p}<0.05)$. No clear or consistent pattern was identified when comparing chemical proxies from different ice core sites.

\section{Discussion}

\subsection{Temporal variability of the diatom record}

The diatom abundance preserved in ice cores reveals a strong interannual variability across the AP and EL regions from 19922019 CE. The relationship between diatom abundance and environmental parameters at the ice core drilling sites are weak and not statistically significant. Indicating that conditions at the ice core site are not drivers of the diatom temporal variability, in agreement with previous studies concluding that ice core diatom records are not dependent on annual snow accumulation or local wind conditions (Allen et al., 2020; Tetzner et al., 2021a).

Spatial correlations of annual wind strength and the annual diatom abundance preserved in ice cores reveal regions of significant positive correlations $(0.6 \leq \mathrm{R} \leq 0.78, \mathrm{p}<0.05)$ (Figure 3 ). These regions match well with the oceanographic zones 
https://doi.org/10.5194/cp-2021-88

Preprint. Discussion started: 22 July 2021

(c) Author(s) 2021. CC BY 4.0 License.

(c) (i)

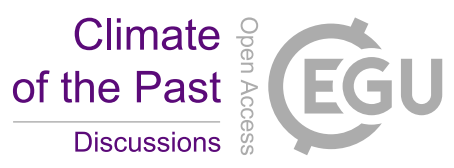

indicated by the ecology of the dominant marine diatom taxa (Tetzner et al., 2021a). Furthermore, the neighbouring ice core sites of JUR and SKBL share similar regions of spatial correlation $(0.67 \leq \mathrm{R} \leq 0.78, \mathrm{p}<0.05)$ (Figure 3). Numerous studies have highlighted the relationship between wind strength and sea-spray production (Blanchard, 1963; Schlichting, 1974; Monahan et al., 1983; Callaghan et al., 2007; Löndahl, 2014; Tesson et al., 2016; Wiśniewska et al., 2019; Marks et al., 2019). Stronger winds have been shown to enhance the production of sea-spray aerosols, including microalgae, which implies an increased transfer of diatoms from the sea-surface microlayer into the atmosphere (Marks et al., 2019). Studies on regional atmospheric circulation confirm that air masses from these regions are effectively transported to ice core sites (Thomas and Bracegirdle, 2009; Abram et al., 2010; Thomas and Bracegirdle, 2015; Allen et al., 2020), therefore establishing an efficient transport pathway from the identified source regions to the ice core sites.

Two oceanographic zones were highlighted in the spatial correlation analyses for their strong link between changes in wind strength and changes in diatom abundance; the seasonal sea ice zone (SSIZ) and permanently open ocean zone (POOZ). The JUR and SKBL diatom records were correlated exclusively with winds in the POOZ (northern Amundsen Sea) and the SHIC spring/summer diatom record was correlated with regions from both the SSIZ (Bryan Coast sector \& Amundsen Sea Embayment) and POOZ (northern Bellingshausen Sea) (Figure 3). It is important to note that these regions of spatial correlation agree with the oceanographic affiliations of the diatom assemblages for the respective ice cores (coastal vs inland sites) reported by Tetzner et al. (2021a). Despite the correlation between the SHIC spring/summer diatom record and winds in the POOZ, the diatom assemblages for SHIC support a stronger link with the SSIZ (Tetzner et al. 2021a). Therefore, discussion

for the SHIC diatom record will be focused on environmental changes within the SSIZ.

\subsubsection{SSIZ controls on diatom variability at a coastal site (SHIC)}

The SSIZ is identified as the dominant source region by both the spatial correlation analyses and the ecological associations of the SHIC diatom record (Tetzner et al., 2021a). Wind strength and sea ice dynamics play an important role in driving the primary productivity in diatom source regions within the SSIZ (Arrigo et al., 2008; Arrigo et al., 2012). In the Bryan Coast and Amundsen Sea Embayment, winds drive sea ice northward producing large ice-free areas (polynyas) near the coast (Arrigo et al., 2012; Holland and Kwok, 2012). These coastal polynyas have been identified as among the most productive regions in the Southern Ocean (Arrigo et al., 2008; Soppa et al., 2016). The stronger link to wind strength during the austral spring and summer (Figure 3), and strong seasonality identified in the sub-annual diatom record reflect the enhanced austral spring/summer primary productivity in these regions (Arrigo et al., 2008; Soppa et al., 2016; Tetzner et al., 2021a). This suggests that the interannual diatom variability at this site is not exclusively driven by wind strength, but also dependent on sea ice dynamics and/or primary productivity. Previous studies have identified recent reductions in the ice-covered days (sea ice concentration) during the austral summer (Stammerjohn et al., 2012) and the development of coastal polynyas (Eltanin Polynya, Pine Island Polynya and Amundsen Sea Polynya) within the regions identified as the SHIC diatom sources (Arrigo and van Dijken, 2003; Arrigo et al., 2012). Both lead to prolonged and increased biogenic primary productivity near the ice core site. Greater sea ice breakup and more open water in summer often result in larger phytoplankton blooms (Soppa et al., 
https://doi.org/10.5194/cp-2021-88

Preprint. Discussion started: 22 July 2021

(c) Author(s) 2021. CC BY 4.0 License.

2016). A prolonged ice-free diatom source and/or recently enhanced primary productivity will increase the availability of diatoms on the ocean surface, favouring potentially larger entrainments of diatoms by strong winds. This is consistent with the recent large decadal increases seen in the SHIC diatom concentration (Tetzner et al., 2021a).

The clear link identified between the seasonality of the diatom record and sea ice primary productivity is complemented by the strong relationship between the austral spring/summer diatom abundance and sea ice cover over the Amundsen Sea. However, no direct relationship was observed between the diatom abundance and the sea ice cover directly in the vicinities of SHIC (Figure 3). This is consistent with the lack of correlation between MSA and sea ice at this site, despite previous studies observing a positive relationship between MSA and sea ice extent in this region (Abram et al., 2010; Thomas and Abram, 2016). These findings suggest that diatom (and MSA) variability at SHIC is not exclusively driven by either marine primary productivity or changes in sea ice cover. This can be explained by the effect of a bi-directional pattern of winds at SHIC, drawing air masses from both the east (Bryan Coast) and the west (Amundsen Sea Embayment) (Tetzner et al., 2019) resulting in two distinct sources of aerosols to the ice core site. Additionally, the onset of the sea ice breakup and duration of ice-free conditions at the Bryan Coast, Eights Coast and the Amundsen Sea Embayment does not follow a clear pattern. Some years present these regions completely ice-free, while others present either one or more regions ice-covered (Arrigo et al., 2008).

The development of coastal polynyas near SHIC (See Figure 1) will contribute to the increased availability of diatoms in some years (Arrigo and van Dijken, 2003; Arrigo et al., 2015). The potential input of diatoms from sources from opposite directions, along with the variability in the distribution and duration of the sea ice cover and the occasional development of coastal polynyas adds an additional and non-negligible source of variability to the diatom record at SHIC.

\subsubsection{POOZ controls on diatom variability at inland sites (JUR and SKBL)}

290 The diatom source region identified by the spatial correlation analyses and diatom ecological affiliations for JUR and SKBL is in the northern Amundsen Sea within the POOZ (Figure 1 and Figure 3). This oceanographic zone is characterized by the lowest seasonal and interannual variability in primary productivity for the whole SO (Arrigo et al., 2008; Soppa et al., 2016). The absence of sea ice in the POOZ reduces the seasonal extremes in primary productivity evident within the SSIZ (Tetzner et al., 2021a). The diatom availability in northern Amundsen Sea POOZ presents a low variability year-round (Arrigo et al.,

295 2008; Soppa et al., 2016), limiting the impact of interannual changes in primary productivity on the diatom record and upholding that temporal variability in the JUR and SKBL diatom records is derived mainly from changes in wind strength at the source. The marine source region supplying diatoms to JUR and SKBL is in the core of the SHWW belt. The significant positive correlation between wind strength and annual diatom abundance $(0.6 \leq \mathrm{R} \leq 0.78, \mathrm{p}<0.05)$ demonstrate the diatom records from these sites can be used as a proxy for interannual changes in the strength of the SHWWs. However, changes in ocean primary productivity may contribute to diatom variability over longer time-scales.

Results presented here are consistent with the relationship identified between SHWWs strength and diatoms in an EL ice core (Allen et al., 2020). Specifically, our results show a close agreement with the location $\left(50-60^{\circ} \mathrm{S}, 140^{\circ} \mathrm{W}\right)$ and magnitude of the strongest correlation $(\mathrm{R}=0.61, \mathrm{p}<0.05)$ between annual SHWW anomalies and calibrated diatom flux at the Ferrigno ice core 
https://doi.org/10.5194/cp-2021-88

Preprint. Discussion started: 22 July 2021

(c) Author(s) 2021. CC BY 4.0 License.

(c) (1)

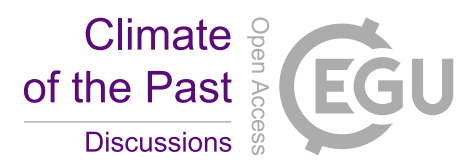

site (Figure 1) (Allen et al., 2020). Unlike JUR and SKBL, the Ferrigno diatom assemblage was characterised by the absence

305 of sea ice diatoms. This can be explained by the more north-westerly location of the Ferrigno diatom source (compared to the JUR and SKBL source region) that is less likely to receive inputs from the SSIZ. Additionally, the absence of sea ice diatoms at Ferrigno supports the conclusion that inland sites have limited influence from low-elevation airmasses in contact with the SSIZ (Tetzner et al., 2021a).

\subsubsection{Recent regional environmental changes and the diatom record}

310 Ice core diatom records have the potential to capture regional environmental changes. The correlation between the annual diatom abundance variability at JUR and SKBL with changes in the wind strength in the SHWW belt (Figure 3) (Figure 4a and 4b) strongly suggests that the recent increase in diatoms at these ice core sites (Tetzner et al., 2021a) is driven by a strengthening of the SHWW belt during the satellite-era (Mayewski et al., 2013; Young and Ribal, 2019; Goyal et al., 2021). This link is further supported by sea-spray production experiments showing that a $\sim 10 \%$ increase in wind strength $\left(\mathrm{U}_{10}>5 \mathrm{~m}\right.$

$315 \mathrm{~s}^{-1}$ ) has the potential to double the production of spume drops and sea-spray aerosol, including microalgae (Monahan et al., 1986; Wu, 1993; Anguelova et al., 1999). Increasing the entrainment of aerosols into the atmosphere would likely increase the supply of diatoms to the ice core sites and therefore the number of diatoms contained in the ice. Despite SHIC exhibiting a similar increase in annual diatom abundance, the intrinsic relationship between the SHIC diatom record, the sea ice cover in SSIZ, and winds over the SSIZ prevents establishing a direct link between the increases in annual diatom abundance at SHIC 320 and the strengthening of the SHWW belt (Figure 4c). 
https://doi.org/10.5194/cp-2021-88

Preprint. Discussion started: 22 July 2021

(c) Author(s) 2021. CC BY 4.0 License.
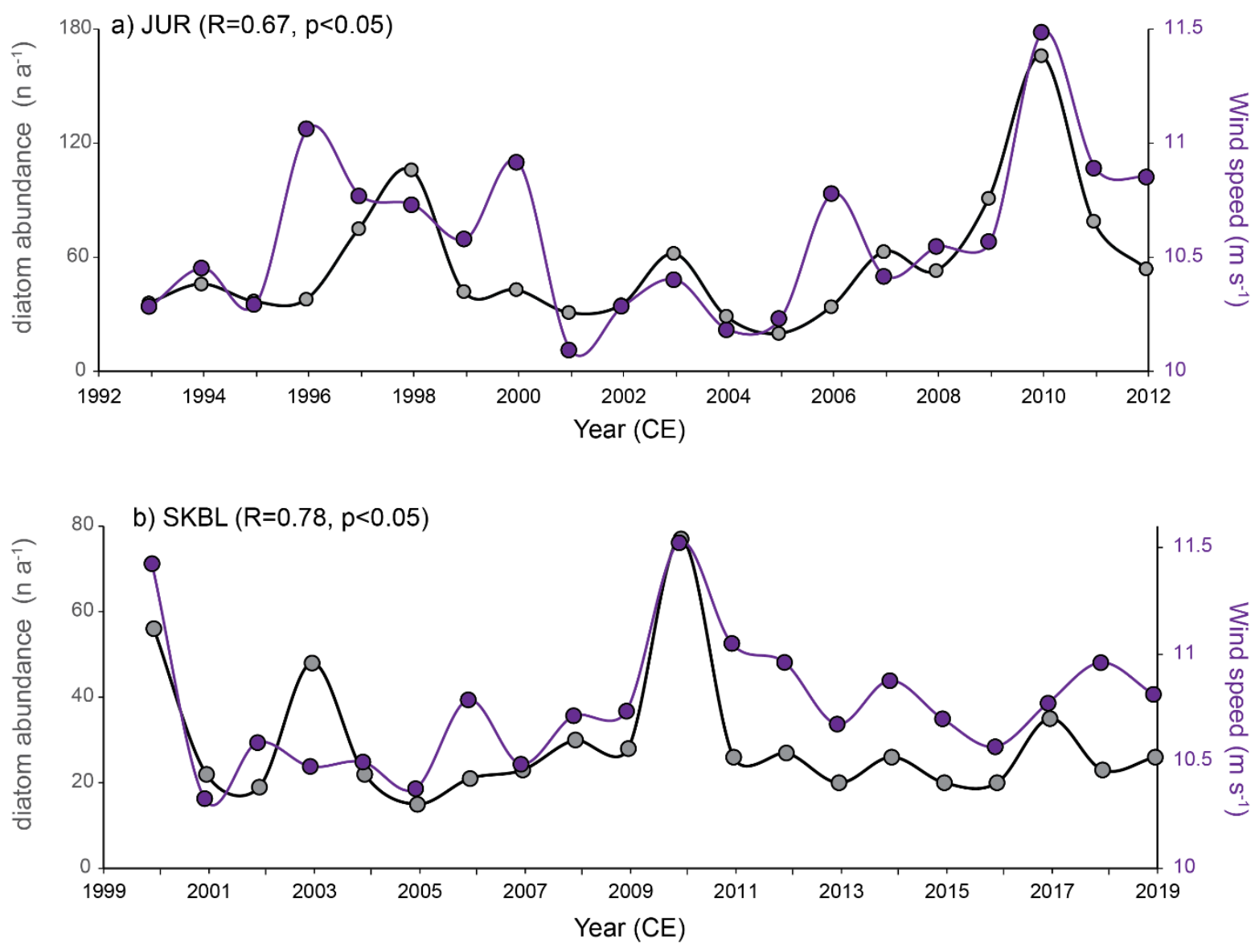

c) $\operatorname{SHIC}(0.64 \leq R \leq 0.71, p<0.05)$

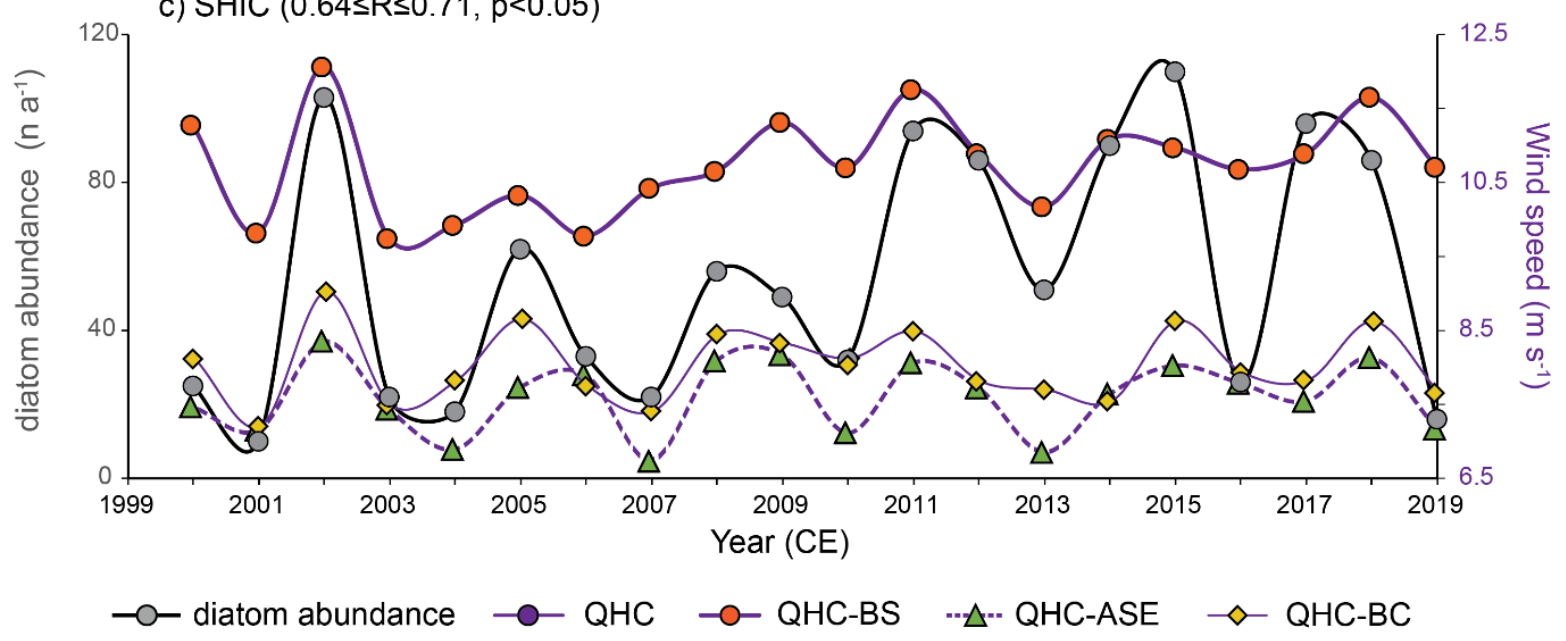

Figure 4. Time series of diatom abundance and mean wind speed inside the quadrants of highest correlation (QHC) for each ice core site highlighted in Figure 3. Data points represent the annual austral winter-to-winter average and were plotted over the correspondent austral summer. Colour-coded symbols for SHIC ice core represent the time series of wind speed on each of the QHC 
https://doi.org/10.5194/cp-2021-88

Preprint. Discussion started: 22 July 2021

(c) Author(s) 2021. CC BY 4.0 License. correlation over the Amundsen Sea Embayment. QHC-BC= Quadrant of high correlation over the Bryan Coast.

\subsection{The diatom wind proxy and the traditional ice core wind proxies}

We have demonstrated that the annual diatom abundance shows promise as a wind proxy of SHWW at multiple sites. To assess the full scope and validity of this novel proxy, we compared the new diatom records with established ice core wind proxies. MPC, $\mathrm{nsSCa}^{2+}, \mathrm{ssNa}^{+}$and $\mathrm{nssK}^{+}$have been used to infer past variability in regional-to-hemispheric atmospheric circulation from annual to millennial timescales. Our results reveal the limitations in these traditional proxies, which fail to reproduce the interannual variability of wind strength upwind from the ice core sites. Instead, they provide only sporadic spatial correlations with annual wind strength that are scattered across the southern mid-latitudes (Figure 3). Even though many of these records show a strong link with wind strength, their region of correlation did not fit with their expected sources and were not consistent between sites. This refutes a direct link between wind strength and their in-situ aerosol production. For example, there are strong correlations between continental-ions $\left(\mathrm{nssK}^{+}\right.$and $\left.\mathrm{nssCa}^{2+}\right)$ and wind strength over regions in the middle of the ocean, where it is not feasible to entrain continental-ions (JUR nssK ${ }^{+}$record). Similarly, some records are strongly linked to other environmental parameters such as precipitation, suggesting that source (JUR nssCa ${ }^{2+}$ record) or site conditions (MPC record at SHIC), rather than wind strength, dominate the variability of these species. Some proxies (MPC at JUR and ssNa ${ }^{+}$at SKBL) were strongly linked to wind strength over regions north $\left(\sim 40-45^{\circ} \mathrm{S}\right)$ of the core of the SHWW belt (Figure 3). This result suggests that these records could indicate changes in wind strength over continental or marine regions far from the core of the SHWW belt. Overall, these results call into question the validity of established wind proxies in the AP and EL ice cores and highlight the need for a thorough site and proxy evaluation before using these chemical and MPC species to reconstruct wind changes through time.

$345 \mathrm{The} \mathrm{ssNa}^{+}$was the only record with a regionally consistent relationship with the diatom abundance (yellow cells in Supplementary material - Table S1). Despite the strong correlations at each ice core site, they presented opposite signs ( $R<0$ for JUR \& R>0 for SHIC and SKBL). Suggesting that the interannual variability of diatom abundance and $\mathrm{ssNa}^{+}$is not driven exclusively by the same environmental parameters across the AP and EL region.

Correlation analyses of ice core proxies between sites confirm that diatom abundance is the only record with a consistent, statistically significant and strong correlation (JUR vs SKBL, R=0.84, p<0.05) (grey cell in Supplementary material - Table $\mathrm{S} 1$ ), supporting the regional validity of the diatom-based wind proxy at the high elevation sites. The nssCa ${ }^{2+}$ record at JUR exhibits significant correlations with winds in the SHWW belt, although not in the same sector as the diatom record. Thus, the significant correlation between these two proxies at JUR $(\mathrm{R}=0.64, \mathrm{p}<0.05)$ provides evidence to support diatoms as a wind proxy. However, the nssCa ${ }^{2+}$ pattern is not reproduced at the nearby SKBL site, suggesting nssCa ${ }^{2+}$ may not be a reliable proxy throughout the AP-EL region.

Previous studies have proposed MPC as a proxy for winds in the AP and EL region (Mosley-Thompson et al., 1990; MosleyThompson et al., 1991; Thompson et al., 1994), suggesting that the MPC record is indicative of long-term regional 
environmental changes. However, low background concentrations reported in those studies suggest the MPC annual record from the AP and EL region could be biased by the occurrence of sporadic major dust events reaching the high southern latitudes. Our results are in close agreement, showing that the regional MPC record preserved in ice cores from the AP and EL is not a robust indicator of interannual wind strength variability. In contrast, the WAIS Divide ice core in neighbouring Marie Byrd Land, revealed a link between the coarse particle percentage (analogous to MPC) and interannual zonal wind strength variability at both $700 \mathrm{hPa}$ and $850 \mathrm{hPa}$ over the satellite-era $(\mathrm{R}=0.3-0.5, \mathrm{p}<0.01)$ (Koffman et al., 2014). This contrasting behaviour can be partly explained by the diametrically opposed continental regions supplying mineral dust to Antarctica (Sudarchikova et al., 2014; Neff and Bertler, 2015). Similarly, differences in transport pathways and the role of local meteorology have also been used to explain the different behaviour observed in sea ice proxies (MSA) around Antarctica (Abram et al., 2013; Thomas et al., 2019). Our findings provide further evidence that ice core proxies perform differently depending on the geographical region and the temporal resolution over which they are assessed.

The temporal variability of chemical tracers $\left(\mathrm{nssCa}^{2+}, \mathrm{nssK}^{+}, \mathrm{ssNa}^{+}\right.$) in a network of ice cores across Marie Byrd Land (ITASE)

have been proposed as tracers of long-term (multi-year) changes in atmospheric circulation (Dixon et al., 2012; Mayewski et al., 2013). However, only nssCa ${ }^{+2}$ proved reliable in capturing interannual variability in atmospheric circulation patterns over the satellite-era $(0.37 \leq \mathrm{R} \leq 0.59, \mathrm{p}<0.01)$, although not directly related to wind strength, but to northerly air mass incursions (Dixon et al., 2012). Thus, there is clearly a need for a reliable proxy for past wind strength in this important region of Antarctica. Based on our results, we propose that diatoms show the most promise as a tool to reconstruct the interannual variability of SHWW strength.

\subsection{Recommendations}

Our findings demonstrate that marine diatoms show the most promise as a proxy for past wind strength in AP and EL ice cores when compared with a range of traditional chemical and MPC records. At inland sites, diatom abundance is most strongly dependent on annual changes in the strength of the SHWWs and has excellent potential as a proxy to reconstruct past changes in the strength of the SHWWs over the northern Amundsen Sea.

Based on our results, we propose three candidate ice core sites across the AP and EL region where multi-decadal to centennial scale reconstructions of winds could be achieved: the Jurassic, Ferrigno and Palmer ice cores (Thomas and Bracegirdle, 2015) (See Figure 1). Evaluations have already confirmed the suitability of the JUR site (this study) and the Ferrigno site (Allen et al., 2020) in reproducing recent changes in the SHWW strength. Previous studies on the Ferrigno ice core have confirmed that this ice core covers the last three centuries (Thomas et al., 2015; Thomas and Abram, 2016), making it a good candidate for extending a SHWW reconstruction back to the core of the Little Ice Age $(\sim 1700 \mathrm{CE})$, while the JUR site has the potential to capture changes over the last two centuries. The diatom record from the Palmer ice core has not yet been explored, however, this high elevation, low snow accumulation site (Thomas and Bracegirdle, 2015) has the potential to hold one of the longest records in the region. An annually-resolved wind strength reconstruction from any of these three ice cores will establish if the 
recent intensification of the SHWW belt is unprecedented over the last few centuries and will clearly identify the timing of onset (Abram et al., 2013; Koffman et al., 2014; Turney et al., 2016; Perren et al., 2020).

Despite the consistency of the observations presented in this work, it must be acknowledged that they are from a particular region in Antarctica. Antarctica is a vast continent with contrasting environmental conditions in different sectors (Jones et al., 2016; Stenni et al., 2017; Thomas et al., 2017; Thomas et al., 2019). Thus, we recommend conducting a detailed assessment of the diatom proxy outside the AP-EL regions.

\section{Conclusions}

Ice cores capture changes in past wind strength and atmospheric variability, with several chemical and microparticles suggested as potential proxies. In this study, we propose an exciting new wind proxy, based on marine diatoms, that performs better than traditional ice core wind proxies in ice cores from the Southern Antarctic Peninsula and Ellsworth Land. A set of ice cores from this region have been analysed to demonstrate that the temporal variability of the diatom record preserved in inland ice cores is exclusively driven by changes in the wind strength within the core of the Southern Hemisphere Westerly Wind belt. While the temporal variability of the diatoms preserved in coastal ice cores is driven by a combination of wind strength and sea ice dynamics within the seasonal sea ice zone.

The lack of coherence between ice core chemical and dust proxies at sites from the same region suggest that these proxies should be used with caution. For these proxies, both the production at the source and the deposition at the ice core sites drive the variability, making it hard to resolve the signal of wind strength. These findings demonstrate the importance of a thorough site evaluation before extending environmental interpretations back in time, with no single proxy suitable for reconstructions across all of Antarctica.

We propose the marine diatom record preserved in ice cores from the Antarctic Peninsula and Ellsworth Land regions is the optimal proxy for reconstructing the interannual wind strength variability in the Pacific sector of the Southern Hemisphere Westerly Wind belt. Further research should be focused on expanding the study of the diatom record and its potential as a wind proxy in other regions of Antarctica and over longer timescales.

\section{Appendix A}

Table A1. Basic statistics for the diatom abundance $\left(\mathrm{n} \mathrm{a}^{-1}\right)$, chemical species $(\mathrm{ppb})$ and MPC (particles $\left.\mathrm{mL}^{-1}\right)$ annual records from 415 each ice core. Bold numbers indicate statistically significant linear trend values $(\mathbf{p}<\mathbf{0 . 0 5})$. (*) MPC record from JUR covers the interval 1992-2011 CE due to missing data.

\begin{tabular}{lccccc}
\hline & Mean & Stdv & Max & Min & Linear trend \\
\hline SHIC (1999-2019 CE) & & & & & \\
\hline Diatom abundance & 54.4 & 33.7 & 110 & 10 & 2.16
\end{tabular}




\begin{tabular}{|c|c|c|c|c|c|}
\hline MPC & 554.80 & 287.44 & 1536.12 & 269.04 & 18.63 \\
\hline $\mathrm{nssCa}^{2+}$ & 20.62 & 7.67 & 41.17 & 12.51 & -0.7 \\
\hline nssK $^{+}$ & 20.56 & 14.13 & 52.65 & 6.71 & -0.48 \\
\hline $\mathbf{s s N a}^{+}$ & 295.38 & 94.38 & 526.82 & 182.34 & 1.61 \\
\hline MSA & 26.09 & 10.96 & 48.3 & 3.76 & -0.09 \\
\hline \multicolumn{6}{|l|}{ JUR (1992-2012 CE) } \\
\hline Diatom abundance & 57.0 & 34.0 & 166 & 20 & 2.07 \\
\hline MPC* & 126.33 & 31.72 & 174.55 & 50.16 & 2.26 \\
\hline $\mathrm{nssCa}^{2+}$ & 69.41 & 26.45 & 136.46 & 45.08 & 3.35 \\
\hline nssK $^{+}$ & 15.6 & 12.16 & 50.62 & 1.83 & 1.23 \\
\hline $\mathbf{s s N a} \mathbf{a}^{+}$ & 43.30 & 19.84 & 85.36 & 7.64 & 2.01 \\
\hline MSA & 15.12 & 4.56 & 24.36 & 5.58 & 0.02 \\
\hline \multicolumn{6}{|c|}{ SKBL (1999-2019 CE) } \\
\hline Diatom abundance & 29.2 & 14.9 & 77 & 15 & -0.41 \\
\hline MPC & 537.60 & 250.19 & 1239.19 & 230.46 & -23.74 \\
\hline $\mathrm{nssCa}^{2+}$ & 15.71 & 4.43 & 24.52 & 9,48 & -0.28 \\
\hline nssK $^{+}$ & 7.00 & 1.41 & 9.57 & 4.44 & -0.2 \\
\hline $\mathbf{s s N a}^{+}$ & 61.04 & 34.94 & 137.62 & 7.44 & 1.31 \\
\hline MSA & 5.91 & 2.52 & 12.35 & 2.44 & -0.01 \\
\hline
\end{tabular}

\section{Data availability}

Datasets original to this work will be available at the UK Polar Data Center (https://www.bas.ac.uk/data/uk-pdc/). 
https://doi.org/10.5194/cp-2021-88

Preprint. Discussion started: 22 July 2021

(c) Author(s) 2021. CC BY 4.0 License.

(c) (i)

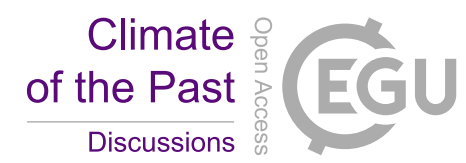

\section{Author contribution}

DT did the initial conceptualization. DT and MG were in charge of data curation. DT, ET and CA conducted the formal analysis. DT was in charge of the Investigation. DT, ET and CA designed the Methodology. DT prepared the original manuscript. ET, CA and MG contributed to the reviewing and editing of the original manuscript.

\section{Competing interests}

425 The authors declare that they have no conflict of interest.

\section{Acknowledgements}

We would like to thank Sarah Crowsley, Tom King, Isobel Rowell and Dr Robert Mulvaney for their help while drilling the SHIC and SKBL ice cores included in this work. We would like to thank Shaun Miller, Dr Jack Humby, Dr Diana Vladimirova and Dr Daniel Emanuelsson from the Ice core Lab, British Antarctic Survey, for their help while cutting the ice and conducting 430 the Continuous Flow Analysis (CFA). We would like to thank Professor Eric Wolff from the Earth Sciences Department, University of Cambridge, for his valuable comments during the final review and editing of this manuscript. SEM work was partly supported by a Royal Society Research Professorships Enhancement Award (RP\EA\180006). We would like to thank Dr Iris Buisman and Dr Giulio Lampronti from the Microscopy Lab, Earth Sciences Department, University of Cambridge, for their technical support in the use of the SEM. Fieldwork conducted for this research was supported by the Collaborative

435 Antarctic Science Scheme (CASS). This research was funded by CONICYT-Becas Chile and Cambridge Trust funding program for PhD studies. Grant number 72180432.

\section{References}

Abram, N. J., Thomas, E. R., McConnell, J. R., Mulvaney, R., Bracegirdle, T. J., Sime, L. C., and Aristarain, A. J.: Ice core evidence for a 20th century decline of sea ice in the Bellingshausen Sea, Antarctica, Journal of Geophysical Research: 440 Atmospheres, 115, https://doi.org/10.1029/2010JD014644, 2010.

Abram, N. J., Wolff, E. W., and Curran, M. A. J.: A review of sea ice proxy information from polar ice cores, Quaternary Science Reviews, 79, 168-183, https://doi.org/10.1016/j.quascirev.2013.01.011, 2013.

Allen, C. S., Thomas, E. R., Blagbrough, H., Tetzner, D. R., Warren, R. A., Ludlow, E. C., and Bracegirdle, T. J.: Preliminary Evidence for the Role Played by South Westerly Wind Strength on the Marine Diatom Content of an Antarctic Peninsula Ice 445 Core (1980-2010), Geosciences, 10, 87, https://doi.org/10.3390/geosciences10030087, 2020.

Anguelova, M., Barber, R. P., and Wu, J.: Spume Drops Produced by the Wind Tearing of Wave Crests, Journal of Physical Oceanography, 29, 1156-1165, https://doi.org/10.1175/1520-0485(1999)029<1156:SDPBTW>2.0.CO;2, 1999. 
https://doi.org/10.5194/cp-2021-88

Preprint. Discussion started: 22 July 2021

(c) Author(s) 2021. CC BY 4.0 License.

Arrigo, K. R. and Dijken, G. L. van: Phytoplankton dynamics within 37 Antarctic coastal polynya systems, Journal of Geophysical Research: Oceans, 108, https://doi.org/10.1029/2002JC001739, 2003.

Arrigo, K. R., Dijken, G. L. van, and Bushinsky, S.: Primary production in the Southern Ocean, 1997-2006, Journal of Geophysical Research: Oceans, 113, https://doi.org/10.1029/2007JC004551, 2008.

Arrigo, K. R., Lowry, K. E., and van Dijken, G. L.: Annual changes in sea ice and phytoplankton in polynyas of the Amundsen Sea, Antarctica, Deep Sea Research Part II: Topical Studies in Oceanography, 71-76, 5-15, https://doi.org/10.1016/j.dsr2.2012.03.006, 2012.

Arrigo, K. R., Dijken, G. L. van, and Strong, A. L.: Environmental controls of marine productivity hot spots around Antarctica, Journal of Geophysical Research: Oceans, 120, 5545-5565, https://doi.org/10.1002/2015JC010888, 2015.

Blanchard, D. C.: The electrification of the atmosphere by particles from bubbles in the sea, Progress in Oceanography, 1, 73202, https://doi.org/10.1016/0079-6611(63)90004-1, 1963.

Bowen, H. J. M.: Environmental chemistry of the elements. Academic Press, London, 1979.

Bracegirdle, T. J., Shuckburgh, E., Sallee, J.-B., Wang, Z., Meijers, A. J. S., Bruneau, N., Phillips, T., and Wilcox, L. J.: Assessment of surface winds over the Atlantic, Indian, and Pacific Ocean sectors of the Southern Ocean in CMIP5 models: historical bias, forcing response, and state dependence, Journal of Geophysical Research: Atmospheres, 118, 547-562, https://doi.org/10.1002/jgrd.50153, 2013.

Budgeon, A. L., Roberts, D., Gasparon, M., and Adams, N.: Direct evidence of aeolian deposition of marine diatoms to an ice sheet, Antarctic Science, 24, 527-535, https://doi.org/10.1017/S0954102012000235, 2012.

Bullard, J. E., Baddock, M., Bradwell, T., Crusius, J., Darlington, E., Gaiero, D., Gassó, S., Gisladottir, G., Hodgkins, R., McCulloch, R., McKenna-Neuman, C., Mockford, T., Stewart, H., and Thorsteinsson, T.: High-latitude dust in the Earth system, Reviews of Geophysics, 54, 447-485, https://doi.org/10.1002/2016RG000518, 2016.

Callaghan, A., Leeuw, G. de, Cohen, L., and O’Dowd, C. D.: Relationship of oceanic whitecap coverage to wind speed and

wind history, Geophysical Research Letters, 35, https://doi.org/10.1029/2008GL036165, 2008.

Chalmers, M. O., Harper, M. A., and Marshall, W. A.: An illustrated catalogue of airborne microbiota from the maritime Antarctic, British Antarctic Survey, Cambridge, 175 pp., 1996.

Cipriano, R. J. and Blanchard, D. C.: Bubble and aerosol spectra produced by a laboratory 'breaking wave,' Journal of Geophysical Research: Oceans, 86, 8085-8092, https://doi.org/10.1029/JC086iC09p08085, 1981.

475 Delmonte, B., Paleari, C. I., Andò, S., Garzanti, E., Andersson, P. S., Petit, J. R., Crosta, X., Narcisi, B., Baroni, C., Salvatore, M. C., Baccolo, G., and Maggi, V.: Causes of dust size variability in central East Antarctica (Dome B): Atmospheric transport from expanded South American sources during Marine Isotope Stage 2, Quaternary Science Reviews, 168, 55-68, https://doi.org/10.1016/j.quascirev.2017.05.009, 2017.

Delmonte, B., Winton, H., Baroni, M., Baccolo, G., Hansson, M., Andersson, P., Baroni, C., Salvatore, M. C., Lanci, L., and 480 Maggi, V.: Holocene dust in East Antarctica: Provenance and variability in time and space, The Holocene, 30, 546-558, https://doi.org/10.1177/0959683619875188, 2020. 
https://doi.org/10.5194/cp-2021-88

Preprint. Discussion started: 22 July 2021

(c) Author(s) 2021. CC BY 4.0 License.

Dixon, D. A., Mayewski, P. A., Goodwin, I. D., Marshall, G. J., Freeman, R., Maasch, K. A., and Sneed, S. B.: An ice-core proxy for northerly air mass incursions into West Antarctica, International Journal of Climatology, 32, 1455-1465, https://doi.org/10.1002/joc.2371, 2012.

Dutrieux, P., Rydt, J. D., Jenkins, A., Holland, P. R., Ha, H. K., Lee, S. H., Steig, E. J., Ding, Q., Abrahamsen, E. P., and Schröder, M.: Strong Sensitivity of Pine Island Ice-Shelf Melting to Climatic Variability, Science, 343, 174-178, https://doi.org/10.1126/science.1244341, 2014.

Farmer, D. M., McNeil, C. L., and Johnson, B. D.: Evidence for the importance of bubbles in increasing air-sea gas flux, Nature, 361, 620-623, https://doi.org/10.1038/361620a0, 1993.

490 Favier, L., Durand, G., Cornford, S. L., Gudmundsson, G. H., Gagliardini, O., Gillet-Chaulet, F., Zwinger, T., Payne, A. J., and Le Brocq, A. M.: Retreat of Pine Island Glacier controlled by marine ice-sheet instability, Nature Clim Change, 4, 117121, https://doi.org/10.1038/nclimate2094, 2014.

Fetterer, F., K. Knowles, W. N. Meier, M. Savoie, and A. K. Windnagel. Sea Ice Index, Version 3. Sea Ice Extent dataset. Boulder, Colorado USA. NSIDC: National Snow and Ice Data Center. https://doi.org/10.7265/N5K072F8, 2017.

495 Frey, M. M., Bales, R. C., and McConnell, J. R.: Climate sensitivity of the century-scale hydrogen peroxide (H2O2) record preserved in 23 ice cores from West Antarctica, Journal of Geophysical Research: Atmospheres, 111, https://doi.org/10.1029/2005JD006816, 2006.

Frey, M. M., Norris, S. J., Brooks, I. M., Anderson, P. S., Nishimura, K., Yang, X., Jones, A. E., Nerentorp Mastromonaco, M. G., Jones, D. H., and Wolff, E. W.: First direct observation of sea salt aerosol production from blowing snow above sea ice, Atmospheric Chemistry and Physics, 20, 2549-2578, https://doi.org/10.5194/acp-20-2549-2020, 2020.

Fritz, S. C., Brinson, B. E., Billups, W. E., and Thompson, L. G.: Diatoms at >5000 Meters in the Quelccaya Summit Dome Glacier, Peru, Arctic, Antarctic, and Alpine Research, 47, 369-374, https://doi.org/10.1657/AAAR0014-075, 2015.

Gayley, R. I., Ram, M., and Stoermer, E. F.: Seasonal variations in diatom abundance and provenance in Greenland ice, Journal of Glaciology, 35, 290-292, https://doi.org/10.3189/S0022143000004664, 1989.

505 Gille, S.: How ice shelves melt, Science, 346, 1180-1181, https://doi.org/10.1126/science.aaa0886, 2014.

Gille, S. T.: Decadal-Scale Temperature Trends in the Southern Hemisphere Ocean, Journal of Climate, 21, 4749-4765, https://doi.org/10.1175/2008JCLI2131.1, 2008.

Goodwin, I. D., van Ommen, T. D., Curran, M. A. J., and Mayewski, P. A.: Mid latitude winter climate variability in the South Indian and southwest Pacific regions since 1300 AD, Climate Dynamics, 22, 783-794, https://doi.org/10.1007/s00382-004-

$\underline{0403-3}, 2004$.

Goyal, R., Gupta, A. S., Jucker, M., and England, M. H.: Historical and Projected Changes in the Southern Hemisphere Surface Westerlies, Geophysical Research Letters, 48, e2020GL090849, https://doi.org/10.1029/2020GL090849, 2021.

Grieman, M. M., Hoffmann, H. M., Humby, J. D., Mulvaney, R., Nehrbass-Ahles, C., Rix, J., Thomas, E. R., Tuckwell, R., and Wolff, E. W.: Continuous flow analysis methods for sodium, magnesium and calcium detection in the Skytrain ice core, 515 Journal of Glaciology, 1-11, https://doi.org/10.1017/jog.2021.75, 2021. 
https://doi.org/10.5194/cp-2021-88

Preprint. Discussion started: 22 July 2021

(c) Author(s) 2021. CC BY 4.0 License.

Harper, M. A. and McKay, R. M.: Diatoms as markers of atmospheric transport, in: The Diatoms: Applications for the Environmental and Earth Sciences, edited by: Stoermer, E. F. and Smol, J. P., Cambridge University Press, Cambridge, 552559, https://doi.org/10.1017/CBO9780511763175.032, 2010.

Hausmann, S., Larocque-Tobler, I., Richard, P. J. H., Pienitz, R., St-Onge, G., and Fye, F.: Diatom-inferred wind activity at Lac du Sommet, southern Québec, Canada: A multiproxy paleoclimate reconstruction based on diatoms, chironomids and pollen for the past 9500 years, The Holocene, 21, 925-938, https://doi.org/10.1177/0959683611400199, 2011.

Hersbach, H., and Dee, D. J. E. N.: ERA5 reanalysis is in production. ECMWF newsletter, 147, 5-6, 2016.

Hodgson, D. A. and Sime, L. C.: Southern westerlies and CO 2, Nature Geosci, 3, 666-667, https://doi.org/10.1038/ngeo970, 2010.

Holland, P. R. and Kwok, R.: Wind-driven trends in Antarctic sea-ice drift, Nature Geosci, 5, 872-875, https://doi.org/10.1038/ngeo1627, 2012.

Holland, P. R., Bracegirdle, T. J., Dutrieux, P., Jenkins, A., and Steig, E. J.: West Antarctic ice loss influenced by internal climate variability and anthropogenic forcing, Nat. Geosci., 12, 718-724, https://doi.org/10.1038/s41561-019-0420-9, 2019.

530 Huang, J. and Jaeglé, L.: Wintertime enhancements of sea salt aerosol in polar regions consistent with a sea ice source from blowing snow, Atmospheric Chemistry and Physics, 17, 3699-3712, https://doi.org/10.5194/acp-17-3699-2017, 2017.

Jacobs, S. S., Jenkins, A., Giulivi, C. F., and Dutrieux, P.: Stronger ocean circulation and increased melting under Pine Island Glacier ice shelf, Nature Geosci, 4, 519-523, https://doi.org/10.1038/ngeo1188, 2011.

Jones, J. M., Gille, S. T., Goosse, H., Abram, N. J., Canziani, P. O., Charman, D. J., Clem, K. R., Crosta, X., de Lavergne, C., 535 Eisenman, I., England, M. H., Fogt, R. L., Frankcombe, L. M., Marshall, G. J., Masson-Delmotte, V., Morrison, A. K., Orsi, A. J., Raphael, M. N., Renwick, J. A., Schneider, D. P., Simpkins, G. R., Steig, E. J., Stenni, B., Swingedouw, D., and Vance, T. R.: Assessing recent trends in high-latitude Southern Hemisphere surface climate, Nature Clim Change, 6, 917-926, https://doi.org/10.1038/nclimate3103, 2016.

Joughin, I., Smith, B. E., and Medley, B.: Marine Ice Sheet Collapse Potentially Under Way for the Thwaites Glacier Basin, 540 West Antarctica, Science, 344, 735-738, https://doi.org/10.1126/science.1249055, 2014.

Kaspari, S., Dixon, D. A., Sneed, S. B., and Handley, M. J.: Sources and transport pathways of marine aerosol species into West Antarctica, Annals of Glaciology, 41, 1-9, https://doi.org/10.3189/172756405781813221, 2005.

Koffman, B. G., Kreutz, K. J., Breton, D. J., Kane, E. J., Winski, D. A., Birkel, S. D., Kurbatov, A. V., and Handley, M. J.: Centennial-scale variability of the Southern Hemisphere westerly wind belt in the eastern Pacific over the past two millennia, 545 Climate of the Past, 10, 1125-1144, https://doi.org/10.5194/cp-10-1125-2014, 2014.

Kreutz, K. J., Mayewski, P. A., Pittalwala, I. I., Meeker, L. D., Twickler, M. S., and Whitlow, S. I.: Sea level pressure variability in the Amundsen Sea region inferred from a West Antarctic glaciochemical record, Journal of Geophysical Research: Atmospheres, 105, 4047-4059, https://doi.org/10.1029/1999JD901069, 2000. 
https://doi.org/10.5194/cp-2021-88

Preprint. Discussion started: 22 July 2021

(c) Author(s) 2021. CC BY 4.0 License.

(c) (i)

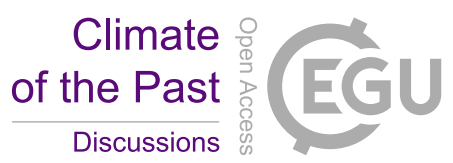

Laluraj, C. M., Rahaman, W., Thamban, M., and Srivastava, R.: Enhanced Dust Influx to South Atlantic Sector of Antarctica

During the Late-20th Century: Causes and Contribution to Radiative Forcing, Journal of Geophysical Research: Atmospheres, 125, e2019JD030675, https://doi.org/10.1029/2019JD030675, 2020.

Lambert, F., Delmonte, B., Petit, J. R., Bigler, M., Kaufmann, P. R., Hutterli, M. A., Stocker, T. F., Ruth, U., Steffensen, J. P., and Maggi, V.: Dust-climate couplings over the past 800,000 years from the EPICA Dome C ice core, Nature, 452, 616-619, https://doi.org/10.1038/nature06763, 2008.

Landschützer, P., Gruber, N., Haumann, F. A., Rödenbeck, C., Bakker, D. C. E., Heuven, S. van, Hoppema, M., Metzl, N., Sweeney, C., Takahashi, T., Tilbrook, B., and Wanninkhof, R.: The reinvigoration of the Southern Ocean carbon sink, Science, 349, 1221-1224, https://doi.org/10.1126/science.aab2620, 2015.

Legrand, M. and Mayewski, P.: Glaciochemistry of polar ice cores: A review, Reviews of Geophysics, 35, 219-243, https://doi.org/10.1029/96RG03527, 1997.

Lichti-Federovich, S. Investigation of diatoms found in surface snow from the Sydkap ice cap, Ellesmere Island, Northwest Territories. Current Research, Geological Survey of Canada, 84-01A, 287-301, https://doi.org/10.4095/119677, 1984.

Löndahl, J.: Physical and biological properties of bioaerosols. Bioaerosol detection technologies, 33-48, https://doi.org/10.1007/978-1-4419-5582-1_3, 2014.

Marks, R., Górecka, E., McCartney, K., and Borkowski, W.: Rising bubbles as mechanism for scavenging and aerosolization of diatoms, Journal of Aerosol Science, 128, 79-88, https://doi.org/10.1016/j.jaerosci.2018.12.003, 2019.

Mayewski, P. A., Maasch, K. A., Dixon, D., Sneed, S. B., Oglesby, R., Korotkikh, E., Potocki, M., Grigholm, B., Kreutz, K., Kurbatov, A. V., Spaulding, N., Stager, J. C., Taylor, K. C., Steig, E. J., White, J., Bertler, N. a. N., Goodwin, I., Simões, J. C., Jaña, R., Kraus, S., and Fastook, J.: West Antarctica's sensitivity to natural and human-forced climate change over the Holocene, Journal of Quaternary Science, 28, 40-48, https://doi.org/10.1002/jqs.2593, 2013.

570 McConnell, J. R., Aristarain, A. J., Banta, J. R., Edwards, P. R., \& Simões, J. C.: 20th-Century doubling in dust archived in an Antarctic Peninsula ice core parallels climate change and desertification in South America. Proceedings of the National Academy of Sciences, 104, 5743-5748, https://doi.org/10.1073/pnas.0607657104, 2007.

McKay, R. M., Barrett, P. J., Harper, M. A., and Hannah, M. J.: Atmospheric transport and concentration of diatoms in surficial and glacial sediments of the Allan Hills, Transantarctic Mountains, Palaeogeography, Palaeoclimatology, Palaeoecology, 260,

575 168-183, https://doi.org/10.1016/j.palaeo.2007.08.014, 2008.

Medley, B. and Thomas, E. R.: Increased snowfall over the Antarctic Ice Sheet mitigated twentieth-century sea-level rise, Nature Clim Change, 9, 34-39, https://doi.org/10.1038/s41558-018-0356-x, 2019.

Monahan, E. C., Fairall, C. W., Davidson, K. L., and Boyle, P. J.: Observed inter-relations between 10m winds, ocean whitecaps and marine aerosols, Quarterly Journal of the Royal Meteorological Society, 109, 379-392, https://doi.org/10.1002/qj.49710946010, 1983. 
https://doi.org/10.5194/cp-2021-88

Preprint. Discussion started: 22 July 2021

(c) Author(s) 2021. CC BY 4.0 License.

Monahan, E. C., Spiel, D. E., and Davidson, K. L.: A Model of Marine Aerosol Generation Via Whitecaps and Wave Disruption, in: Oceanic Whitecaps: And Their Role in Air-Sea Exchange Processes, edited by: Monahan, E. C. and Niocaill, G. M., Springer Netherlands, Dordrecht, 167-174, https://doi.org/10.1007/978-94-009-4668-2_16, 1986.

Mosley-Thompson, E., Thompson, L. G., Grootes, P. M., and Gundestrup, N.: Little Ice Age (Neoglacial) Paleoenvironmental

585 Conditions At Siple Station, Antarctica, Annals of Glaciology, 14, 199-204, https://doi.org/10.3189/S0260305500008570, 1990.

Mosley-Thompson, E., Dai, J., Thompson, L. G., Grootes, P. M., Arbogast, J. K., and Paskievitch, J. F.: Glaciological studies at Siple Station (Antarctica): potential ice-core paleoclimatic record, Journal of Glaciology, 37, 11-22, https://doi.org/10.3189/S002214300004274X, 1991.

590 Nakayama, Y., Menemenlis, D., Zhang, H., Schodlok, M., and Rignot, E.: Origin of Circumpolar Deep Water intruding onto the Amundsen and Bellingshausen Sea continental shelves, Nat Commun, 9, 3403, https://doi.org/10.1038/s41467-018-05813$1,2018$.

Neff, P. D. and Bertler, N. A. N.: Trajectory modeling of modern dust transport to the Southern Ocean and Antarctica, Journal of Geophysical Research: Atmospheres, 120, 9303-9322, https://doi.org/10.1002/2015JD023304, 2015.

595 Oliva, M., Navarro, F., Hrbáček, F., Hernández, A., Nývlt, D., Pereira, P., Ruiz-Fernández, J., and Trigo, R.: Recent regional climate cooling on the Antarctic Peninsula and associated impacts on the cryosphere, Science of The Total Environment, 580, 210-223, https://doi.org/10.1016/j.scitotenv.2016.12.030, 2017.

Paolo, F. S., Fricker, H. A., and Padman, L.: Volume loss from Antarctic ice shelves is accelerating, Science, 348, 327-331, https://doi.org/10.1126/science.aaa0940, 2015.

600 Papina, T., Blyakharchuk, T., Eichler, A., Malygina, N., Mitrofanova, E., and Schwikowski, M.: Biological proxies recorded in a Belukha ice core, Russian Altai, Climate of the Past, 9, 2399-2411, https://doi.org/10.5194/cp-9-2399-2013, 2013.

Pasteris, D. R., McConnell, J. R., Das, S. B., Criscitiello, A. S., Evans, M. J., Maselli, O. J., Sigl, M., and Layman, L.: Seasonally resolved ice core records from West Antarctica indicate a sea ice source of sea-salt aerosol and a biomass burning source of ammonium, Journal of Geophysical Research: Atmospheres, 119, 9168-9182,

605 https://doi.org/10.1002/2013JD020720, 2014.

Perren, B. B., Hodgson, D. A., Roberts, S. J., Sime, L., Van Nieuwenhuyze, W., Verleyen, E., and Vyverman, W.: Southward migration of the Southern Hemisphere westerly winds corresponds with warming climate over centennial timescales, Commun Earth Environ, 1, 1-8, https://doi.org/10.1038/s43247-020-00059-6, 2020.

Piel, C., Weller, R., Huke, M., and Wagenbach, D.: Atmospheric methane sulfonate and non-sea-salt sulfate records at the 610 European Project for Ice Coring in Antarctica (EPICA) deep-drilling site in Dronning Maud Land, Antarctica, Journal of Geophysical Research: Atmospheres, 111, https://doi.org/10.1029/2005JD006213, 2006.

Pritchard, H. D., Ligtenberg, S. R. M., Fricker, H. A., Vaughan, D. G., van den Broeke, M. R., and Padman, L.: Antarctic icesheet loss driven by basal melting of ice shelves, Nature, 484, 502-505, https://doi.org/10.1038/nature10968, 2012. 
https://doi.org/10.5194/cp-2021-88

Preprint. Discussion started: 22 July 2021

(c) Author(s) 2021. CC BY 4.0 License.

Quéré, C. L., Rödenbeck, C., Buitenhuis, E. T., Conway, T. J., Langenfelds, R., Gomez, A., Labuschagne, C., Ramonet, M.,

Nakazawa, T., Metzl, N., Gillett, N., and Heimann, M.: Saturation of the Southern Ocean CO2 Sink Due to Recent Climate Change, Science, 316, 1735-1738, https://doi.org/10.1126/science.1136188, 2007.

Rankin, A. M., Auld, V., and Wolff, E. W.: Frost flowers as a source of fractionated sea salt aerosol in the polar regions, Geophysical Research Letters, 27, 3469-3472, https://doi.org/10.1029/2000GL011771, 2000.

Rankin, A. M., Wolff, E. W., and Martin, S.: Frost flowers: Implications for tropospheric chemistry and ice core interpretation,

Journal of Geophysical Research: Atmospheres, 107, AAC 4-1-AAC 4-15, https://doi.org/10.1029/2002JD002492, 2002.

Röthlisberger, R., Mulvaney, R., Wolff, E. W., Hutterli, M. A., Bigler, M., Sommer, S., and Jouzel, J.: Dust and sea salt variability in central East Antarctica (Dome C) over the last $45 \mathrm{kyrs}$ and its implications for southern high-latitude climate, Geophysical Research Letters, 29, 24-1-24-4, https://doi.org/10.1029/2002GL015186, 2002.

Russell, J. L., Dixon, K. W., Gnanadesikan, A., Stouffer, R. J., and Toggweiler, J. R.: The Southern Hemisphere Westerlies in

a Warming World: Propping Open the Door to the Deep Ocean, Journal of Climate, 19, 6382-6390, https://doi.org/10.1175/JCLI3984.1, 2006.

Schlichting, H. E.: Ejection of microalgae into the air via bursting bubbles, Journal of Allergy and Clinical Immunology, 53, 185-188, https://doi.org/10.1016/0091-6749(74)90006-2, 1974.

Smol, J. P. and Stoermer, E. F. (Eds.): The Diatoms: Applications for the Environmental and Earth Sciences, 2nd ed.,

630 Cambridge University Press, Cambridge, https://doi.org/10.1017/CBO9780511763175, 2010.

Soppa, M. A., Völker, C., and Bracher, A.: Diatom Phenology in the Southern Ocean: Mean Patterns, Trends and the Role of Climate Oscillations, Remote Sensing, 8, 420, https://doi.org/10.3390/rs8050420, 2016.

Spaulding, S. A., Van de Vijver, B., Hodgson, D. A., McKnight, D. M., Verleyen, E., and Stanish, L.: Diatoms as indicators of environmental change in Antarctic and subantarctic freshwaters, in: The Diatoms: Applications for the Environmental and

635 Earth Sciences, edited by: Stoermer, E. F. and Smol, J. P., Cambridge University Press, Cambridge, 267-284, https://doi.org/10.1017/CBO9780511763175.015, 2010.

Stammerjohn, S., Massom, R., Rind, D., and Martinson, D.: Regions of rapid sea ice change: An inter-hemispheric seasonal comparison, Geophysical Research Letters, 39, https://doi.org/10.1029/2012GL050874, 2012.

Steig, E. J., Ding, Q., Battisti, D. S., and Jenkins, A.: Tropical forcing of Circumpolar Deep Water Inflow and outlet glacier

640 thinning in the Amundsen Sea Embayment, West Antarctica, Annals of Glaciology, 53, 19-28, https://doi.org/10.3189/2012AoG60A110, 2012.

Stenni, B., Curran, M. A. J., Abram, N. J., Orsi, A., Goursaud, S., Masson-Delmotte, V., Neukom, R., Goosse, H., Divine, D., van Ommen, T., Steig, E. J., Dixon, D. A., Thomas, E. R., Bertler, N. A. N., Isaksson, E., Ekaykin, A., Werner, M., and Frezzotti, M.: Antarctic climate variability on regional and continental scales over the last 2000 years, Climate of the Past, 13, 645 1609-1634, https://doi.org/10.5194/cp-13-1609-2017, 2017. 
https://doi.org/10.5194/cp-2021-88

Preprint. Discussion started: 22 July 2021

(c) Author(s) 2021. CC BY 4.0 License.

Sudarchikova, N., Mikolajewicz, U., Timmreck, C., O’Donnell, D., Schurgers, G., Sein, D., and Zhang, K.: Dust deposition in Antarctica in glacial and interglacial climate conditions: a modelling study, Climate of the Past, 10, 3715-3753, https://doi.org/10.5194/cpd-10-3715-2014, 2014.

Tesson, S. V. M., Skjøth, C. A., Šantl-Temkiv, T., and Löndahl, J.: Airborne Microalgae: Insights, Opportunities, and

Challenges, Applied and Environmental Microbiology, 82, 1978-1991, https://doi.org/10.1128/AEM.03333-15, 2016.

Tetzner, D., Thomas, E., and Allen, C.: A Validation of ERA5 Reanalysis Data in the Southern Antarctic Peninsula—Ellsworth

Land Region, and Its Implications for Ice Core Studies, Geosciences, 9, 289, https://doi.org/10.3390/geosciences9070289, 2019.

Tetzner, D. R., Thomas, E. R., and Allen, C. S.: Marine diatoms in ice cores from the Antarctic Peninsula and Ellsworth Land,

655 Antarctica; species diversity and regional variability, The Cryosphere Discussions, 1-32, https://doi.org/10.5194/tc-2021-160, 2021a.

Tetzner, D. R., Thomas, E. R., Allen, C. S., Piermattei, A. Evidence of recent active volcanism in the Balleny Islands (Antarctica) from ice core records, ESSOAr [preprint], 10.1002/essoar.10507039.1, 12 May 2021b.

Tetzner, D., Thomas, E. R., Allen, C. S., and Wolff, E. W.: A Refined Method to Analyze Insoluble Particulate Matter in Ice

660 Cores, and Its Application to Diatom Sampling in the Antarctic Peninsula, Front. Earth Sci., 9, https://doi.org/10.3389/feart.2021.617043, 2021c.

Thoen, I. U., Simões, J. C., Lindau, F. G. L., and Sneed, S. B.: Ionic content in an ice core from the West Antarctic Ice Sheet: 1882-2008 A.D., Braz. J. Geol., 48, 853-865, https://doi.org/10.1590/2317-4889201820180037, 2018.

Thoma, M., Jenkins, A., Holland, D., and Jacobs, S.: Modelling Circumpolar Deep Water intrusions on the Amundsen Sea continental shelf, Antarctica, Geophysical Research Letters, 35, https://doi.org/10.1029/2008GL034939, 2008.

Thomas, E. R. and Abram, N. J.: Ice core reconstruction of sea ice change in the Amundsen-Ross Seas since 1702 A.D., Geophysical Research Letters, 43, 5309-5317, https://doi.org/10.1002/2016GL068130, 2016.

Thomas, E. R. and Bracegirdle, T. J.: Improving ice core interpretation using in situ and reanalysis data, Journal of Geophysical Research: Atmospheres, 114, https://doi.org/10.1029/2009JD012263, 2009.

670 Thomas, E. R. and Bracegirdle, T. J.: Precipitation pathways for five new ice core sites in Ellsworth Land, West Antarctica, Clim Dyn, 44, 2067-2078, https://doi.org/10.1007/s00382-014-2213-6, 2015.

Thomas, E. R. and Tetzner, D. R.: The Climate of the Antarctic Peninsula during the Twentieth Century: Evidence from Ice Cores, IntechOpen, https://doi.org/10.5772/intechopen.81507, 2018.

Thomas, E. R., Marshall, G. J., and McConnell, J. R.: A doubling in snow accumulation in the western Antarctic Peninsula since 1850, Geophysical Research Letters, 35, https://doi.org/10.1029/2007GL032529, 2008.

Thomas, E. R., Dennis, P. F., Bracegirdle, T. J., and Franzke, C.: Ice core evidence for significant 100-year regional warming on the Antarctic Peninsula, Geophysical Research Letters, 36, https://doi.org/10.1029/2009GL040104, 2009.

Thomas, E. R., Bracegirdle, T. J., Turner, J., and Wolff, E. W.: A 308 year record of climate variability in West Antarctica, Geophysical Research Letters, 40, 5492-5496, https://doi.org/10.1002/2013GL057782, 2013. 
https://doi.org/10.5194/cp-2021-88

Preprint. Discussion started: 22 July 2021

(c) Author(s) 2021. CC BY 4.0 License.

680 Thomas, E. R., Hosking, J. S., Tuckwell, R. R., Warren, R. A., and Ludlow, E. C.: Twentieth century increase in snowfall in coastal West Antarctica, Geophysical Research Letters, 42, 9387-9393, https://doi.org/10.1002/2015GL065750, 2015.

Thomas, E. R., van Wessem, J. M., Roberts, J., Isaksson, E., Schlosser, E., Fudge, T. J., Vallelonga, P., Medley, B., Lenaerts, J., Bertler, N., van den Broeke, M. R., Dixon, D. A., Frezzotti, M., Stenni, B., Curran, M., and Ekaykin, A. A.: Regional Antarctic snow accumulation over the past 1000 years, Climate of the Past, 13, 1491-1513, https://doi.org/10.5194/cp-13685 1491-2017, 2017.

Thomas, E. R., Allen, C. S., Etourneau, J., King, A. C. F., Severi, M., Winton, V. H. L., Mueller, J., Crosta, X., and Peck, V. L.: Antarctic Sea Ice Proxies from Marine and Ice Core Archives Suitable for Reconstructing Sea Ice over the Past 2000 Years, Geosciences, 9, 506, https://doi.org/10.3390/geosciences9120506, 2019.

Thompson, D. W. J. and Solomon, S.: Interpretation of Recent Southern Hemisphere Climate Change, Science, 296, 895-899, 690 https://doi.org/10.1126/science.1069270, 2002.

Thompson, L. G., Peel, D. A., Mosley-thompson, E., Mulvaney, R., Dal, J., Lin, P. N., Davis, M. E., and Raymond, C. F.: Climate since AD 1510 on Dyer Plateau, Antarctic Peninsula: evidence for recent climate change, Annals of Glaciology, 20, 420-426, https://doi.org/10.3189/1994AoG20-1-420-426, 1994.

Turner, J., Marshall, G. J., Clem, K., Colwell, S., Phillips, T., and Lu, H.: Antarctic temperature variability and change from 695 station data, International Journal of Climatology, 40, 2986-3007, https://doi.org/10.1002/joc.6378, 2020.

Turney, C. S. M., Jones, R. T., Fogwill, C., Hatton, J., Williams, A. N., Hogg, A., Thomas, Z. A., Palmer, J., Mooney, S., and Reimer, R. W.: A 250-year periodicity in Southern Hemisphere westerly winds over the last 2600 years, Climate of the Past, 12, 189-200, https://doi.org/10.5194/cp-12-189-2016, 2016.

Vance, T. R., Ommen, T. D. van, Curran, M. A. J., Plummer, C. T., and Moy, A. D.: A Millennial Proxy Record of ENSO and

700 Eastern Australian Rainfall from the Law Dome Ice Core, East Antarctica, Journal of Climate, 26, 710-725, https://doi.org/10.1175/JCLI-D-12-00003.1, 2013.

Wagenbach, D., Ducroz, F., Mulvaney, R., Keck, L., Minikin, A., Legrand, M., Hall, J. S., and Wolff, E. W.: Sea-salt aerosol in coastal Antarctic regions, Journal of Geophysical Research: Atmospheres, 103, 10961-10974, https://doi.org/10.1029/97JD01804, 1998.

705 Wåhlin, A. K., Kalén, O., Arneborg, L., Björk, G., Carvajal, G. K., Ha, H. K., Kim, T. W., Lee, S. H., Lee, J. H., and Stranne, C.: Variability of Warm Deep Water Inflow in a Submarine Trough on the Amundsen Sea Shelf, Journal of Physical Oceanography, 43, 2054-2070, https://doi.org/10.1175/JPO-D-12-0157.1, 2013.

Wang, L., Lu, H., Liu, J., Gu, Z., Mingram, J., Chu, G., Li, J., Rioual, P., Negendank, J. F. W., Han, J., and Liu, T.: Diatombased inference of variations in the strength of Asian winter monsoon winds between 17,500 and 6000 calendar years B.P., 710 Journal of Geophysical Research: Atmospheres, 113, https://doi.org/10.1029/2008JD010145, 2008.

Warnock, J. P. and Scherer, R. P.: Diatom species abundance and morphologically-based dissolution proxies in coastal Southern Ocean assemblages, Continental Shelf Research, 102, 1-8, https://doi.org/10.1016/j.csr.2015.04.012, 2015. 
https://doi.org/10.5194/cp-2021-88

Preprint. Discussion started: 22 July 2021

(c) Author(s) 2021. CC BY 4.0 License.

(c) (i)

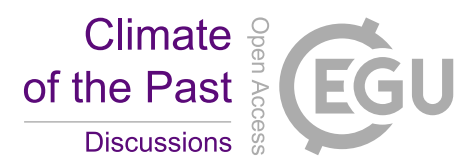

Wiśniewska, K., Lewandowska, A. U., and Śliwińska-Wilczewska, S.: The importance of cyanobacteria and microalgae present in aerosols to human health and the environment - Review study, Environment International, 131, 104964, 715 https://doi.org/10.1016/j.envint.2019.104964, 2019.

Wolff, E. W., Rankin, A. M., and Röthlisberger, R.: An ice core indicator of Antarctic sea ice production?, Geophysical Research Letters, 30, https://doi.org/10.1029/2003GL018454, 2003.

Wolff, E. W., Fischer, H., Fundel, F., Ruth, U., Twarloh, B., Littot, G. C., Mulvaney, R., Röthlisberger, R., de Angelis, M., Boutron, C. F., Hansson, M., Jonsell, U., Hutterli, M. A., Lambert, F., Kaufmann, P., Stauffer, B., Stocker, T. F., Steffensen, 720 J. P., Bigler, M., Siggaard-Andersen, M. L., Udisti, R., Becagli, S., Castellano, E., Severi, M., Wagenbach, D., Barbante, C., Gabrielli, P., and Gaspari, V.: Southern Ocean sea-ice extent, productivity and iron flux over the past eight glacial cycles, Nature, 440, 491-496, https://doi.org/10.1038/nature04614, 2006.

Wolff, E. W., Barbante, C., Becagli, S., Bigler, M., Boutron, C. F., Castellano, E., de Angelis, M., Federer, U., Fischer, H., Fundel, F., Hansson, M., Hutterli, M., Jonsell, U., Karlin, T., Kaufmann, P., Lambert, F., Littot, G. C., Mulvaney, R., 725 Röthlisberger, R., Ruth, U., Severi, M., Siggaard-Andersen, M. L., Sime, L. C., Steffensen, J. P., Stocker, T. F., Traversi, R., Twarloh, B., Udisti, R., Wagenbach, D., and Wegner, A.: Changes in environment over the last 800,000 years from chemical analysis of the EPICA Dome C ice core, Quaternary Science Reviews, 29, 285-295, https://doi.org/10.1016/j.quascirev.2009.06.013, 2010.

$\mathrm{Wu}, \mathrm{J} .:$ Production of spume drops by the wind tearing of wave crests: The search for quantification, Journal of Geophysical 730 Research: Oceans, 98, 18221-18227, https://doi.org/10.1029/93JC01834, 1993.

Young, I. R. and Ribal, A.: Multiplatform evaluation of global trends in wind speed and wave height, Science, 364, 548-552, https://doi.org/10.1126/science.aav9527, 2019.

Young, I. R., Zieger, S., and Babanin, A. V.: Global Trends in Wind Speed and Wave Height, Science, 332, 451-455, https://doi.org/10.1126/science.1197219, 2011. 